\title{
Bio-Based Plasticized PVA Based Polymer Blend Electrolytes for Energy Storage EDLC Devices: Ion Transport Parameters and Electrochemical Properties
}

\author{
Shujahadeen B. Aziz 1,2,*(D), Muaffaq M. Nofal ${ }^{3} \mathbb{D}$, M. F. Z. Kadir ${ }^{4}$, Elham M. A. Dannoun ${ }^{5} \mathbb{D}$, Mohamad A. Brza $^{6}$, \\ Jihad M. Hadi ${ }^{7}$ (D) and Ranjdar M. Abdullah ${ }^{1}$
}

\section{check for} updates

Citation: Aziz, S.B.; Nofal, M.M.; Kadir, M.F.Z.; Dannoun, E.M.A.; Brza, M.A.; Hadi, J.M.; Abdullah, R.M. Bio-Based Plasticized PVA Based Polymer Blend Electrolytes for Energy Storage EDLC Devices: Ion Transport Parameters and Electrochemical Properties. Materials 2021, 14, 1994. https://doi.org/10.3390/ma14081994

Academic Editors: Jang Myoun Ko and Mária Omastová

Received: 10 March 2021

Accepted: 14 April 2021

Published: 16 April 2021

Publisher's Note: MDPI stays neutral with regard to jurisdictional claims in published maps and institutional affiliations.

Copyright: (c) 2021 by the authors. Licensee MDPI, Basel, Switzerland. This article is an open access article distributed under the terms and conditions of the Creative Commons Attribution (CC BY) license (https:// creativecommons.org/licenses/by/ $4.0 /)$.
1 Hameed Majid Advanced Polymeric Materials Research Lab., Physics Department, College of Science, University of Sulaimani, Qlyasan Street, Sulaimani 46001, Iraq; ranjdar.abdullah@univsul.edu.iq

2 Department of Civil Engineering, College of Engineering, Komar University of Science and Technology, Sulaimani 46001, Iraq

3 Department of Mathematics and General Sciences, Prince Sultan University, P.O. Box 66833, Riyadh 11586, Saudi Arabia; muaffaqnofal@gmail.com

4 Centre for Foundation Studies in Science, University of Malaya, Kuala Lumpur 50603, Malaysia; mfzkadir@um.edu.my

5 Associate Director of General Science Department, Woman Campus, Prince Sultan University, P.O. Box 66833, Riyadh 11586, Saudi Arabia; elhamdannoun1977@gmail.com

6 Department of Manufacturing and Materials Engineering, Faculty of Engineering, International Islamic University of Malaysia, Kuala Lumpur 53100, Malaysia; mohamad.brza@gmail.com

7 Department of Medical Laboratory of Science, College of Health Sciences, University of Human Development, Sulaimani 46001, Iraq; jihad.chemist@gmail.com

* Correspondence: shujahadeenaziz@gmail.com

Abstract: This report shows a simple solution cast methodology to prepare plasticized polyvinyl alcohol (PVA)/methylcellulose (MC)-ammonium iodide $\left(\mathrm{NH}_{4} \mathrm{I}\right)$ electrolyte at room temperature. The maximum conducting membrane has a conductivity of $3.21 \times 10^{-3} \mathrm{~S} / \mathrm{cm}$. It is shown that the number density, mobility and diffusion coefficient of ions are enhanced by increasing the glycerol. A number of electric and electrochemical properties of the electrolyte-impedance, dielectric properties, transference numbers, potential window, energy density, specific capacitance $\left(C_{s}\right)$ and power densitywere determined. From the determined electric and electrochemical properties, it is shown that PVA: $\mathrm{MC}-\mathrm{NH}_{4} \mathrm{I}$ proton conducting polymer electrolyte (PE) is adequate for utilization in energy storage device (ESD). The decrease of charge transfer resistance with increasing plasticizer was observed from Bode plot. The analysis of dielectric properties has indicated that the plasticizer is a novel approach to increase the number of charge carriers. The electron and ion transference numbers were found. From the linear sweep voltammetry (LSV) response, the breakdown voltage of the electrolyte is determined. From Galvanostatic charge-discharge (GCD) measurement, the calculated $C_{s}$ values are found to drop with increasing the number of cycles. The increment of internal resistance is shown by equivalent series resistance (ESR) plot. The energy and power density were studied over 250 cycles that results to the value of $5.38-3.59 \mathrm{Wh} / \mathrm{kg}$ and $757.58-347.22 \mathrm{~W} / \mathrm{kg}$, respectively.

Keywords: PVA; methylcellulose; glycerol plasticizer; circuit modeling; ion transport parameters; electrochemical properties; EDLC fabrication

\section{Introduction}

The field of polymer electrolytes (PEs) is extended from polymer science to a number of areas, including electrochemistry organic chemistry and even inorganic chemistry. Rapid change in human lifestyle demands high performance energy storage devices (ESDs) [1,2]. The conducting PEs were greatly developed in this era due to their promising performance for the ESDs applications such as electrochemical double layer capacitor (EDLC) and proton batteries. The mentioned applications have been recognized as promising replacements 
to conventional batteries because of their cost effective and simple fabrication method with a satisfactory performance, which is able to achieve good values of power density and specific capacitance [1-3]. The most used electrode material for the construction of EDLC is activated carbon. Earlier studies have proven that the activated carbon electrode with large and porous surface area causes an increase of conductivity and other important EDLC parameters such as energy and power density [4]. A non-Faradaic mechanism of energy storage (ES) is used in the EDLC where a double layer (DL) at the area of the electrolyte-electrode is created by the ions transfer or accumulation of charges where there is no involvement of electrons [5]. The usage of solid polymer electrolyte (SPE) in these applications has also been acknowledged by few researchers because of their ability to provide good mechanical stability and good electrolyte/electrode contact [6]. SPEs also have much less tendency to harm the internal components of the devices because they circumvent leaking and corrosive problems that are possessed by liquid electrolyte [79]. Verma et al. [10] prepared nano-composite $\mathrm{PE}$ of $95(70 \mathrm{PEO}-30 \mathrm{AgI})-5 \mathrm{SiO}_{2}$ with the conductivity value of $2.5 \times 10^{-3} \mathrm{~S} / \mathrm{cm}$. They showed that the electrolyte is appropriate for applications in solid capacitor owing to the conductivity improvement and enhancement in amorphous phase. The preparation of process of SPEs is also straightforward and the electrolyte itself is long lasting [11]. The blend of PEs is shown to create an exceptional electrolyte film with good thermal and chemical durability that appropriate to be applied in a particular application [12]. This is because the technique of blending has confirmed to enrich the vacant sites for ions to hop through the PEs therefore, improve the conductivity of the film $[13,14]$.

The polyvinyl alcohol (PVA) polymer has been widely utilized in conducting PE in two forms: pure polymer [15-17] and blended polymer including polyvinyl pyrrolidone [18], arginine [19] and carboxymethyl cellulose [20]. For reformulation of PEs, PVA is one of appropriate polymers because of several advantageous properties, including semi-crystalline, non-toxicity, satisfactory strength and sufficient charge storing capability [21,22]. It is also worth-mentioning that PVA contains hydroxyl group $(-\mathrm{OH})$ in the methyl carbon which forms hydrogen bonding [16]. Similarly, methyl cellulose (MC) as a derivative of cellulose is an alternative of PVA. The methyl cellulose (MC) consists of $\beta$-(1,4)-glycosidic bond attached to methyl substituents in linear chains [23] that is capable of providing polarity via oxygen atoms that contain lone pair electrons [24]. It is also of great importance to know that MC possesses amphiphile property originating from hydrophobic polysaccharide and hydrophilic carboxylic functional group [25].

The usage of single MC-based electrolytes in this field has been documented [26-28]. It has also been used by mixing with potato starch [29], maize starch [30] and chitosan [31]. This is due to unique properties of MC, such as non-toxicity, biocompatibility, mechanical strengthens and thermal stability [32]. The ionic conductivity of an electrolyte has to be determined and sufficient to be used in energy devices. This property can be enhanced via either salts and/or plasticizers additions [33,34]. The small size ion, such as $\mathrm{Li}^{+}$ion has widely been utilized; however, it is harmful to environment because of non-biodegradability and expensiveness [35].

To solve this issue, ammonium-based salts, for instance ammonium iodide $\left(\mathrm{NH}_{4} \mathrm{I}\right)$ has replaced lithium salt effectively by providing cation and anion to PE composites [36]. For instance, $\mathrm{NH}_{4} \mathrm{I}$ has a low lattice energy of $605.3 \mathrm{~kJ} / \mathrm{mol}$, indicating a high degree of salt dissociation into ions [37]. Moreover, ammonium-based salts are commonly used in the formulation of PE system because they could accomplish high ionic conductivity with good compatibility and thermal stability [38]. Additionally, the addition of plasticizers into PE could also modify the basic interaction of polymers and affects the ionic conductivity of the system [39]. Various types of plasticizers have been reported in other works such as polyethylene glycol [24], propylene carbonate [40] and ethylene carbonate [41]. Most of the PE that would be fabricated in the energy devices is formulated by adding glycerol to enhance the ionic conductivity as well as other important parameters [42,43]. Furthermore, glycerol has been proven to increase the ionic conductivity up to $\sim 10^{-3} \mathrm{~S} / \mathrm{cm}$, by creating 
more pathways for ions conduction hence revealing an adequate achievement in EDLC application, where the energy and power densities were $3.1 \mathrm{Wh} / \mathrm{kg}$ and $910-385 \mathrm{~W} / \mathrm{kg}$, respectively, with cycle number of 1000 [44]. Additionally, glycerol reduces the electrostatic force amongst cations and anions of the salt and thus produce more mobile ions [44]. An electrolyte film and two electrodes' materials are inserted in the EDLC device. Generally, supercapacitors (SCs) are made using carbon-based electrodes [45]. The various carbonbased electrodes used in EDLCs are carbon nano-tubes, carbon nano-fibers, carbon aerogels, activated carbon (AC), graphites and carbon nano-size [46]. The electrode material is used in this work is AC owing to its high porosity with more than $2 \mathrm{~nm}$ in pore width, high conductivity, large surface area with more than $1000 \mathrm{~m}^{2} \mathrm{~g}^{-1}$, cost effectiveness and chemical stability $[47,48]$. AC has high surface area of $2500 \mathrm{~m}^{2} / \mathrm{g}$ compared with the carbon black (CB). More ions could be adsorbed due to high surface area of AC and hence the DL is synthesized because of the ion accumulation. This is why the AC is known as the active material. CB has a very small surface area and would be used to enhance the electrodes electrical conductivity [2]. This work reports the effect of PE that is formulated with different concentration of glycerol using several experimental techniques. The most favorable electrolyte with the highest conductivity value will be applied in the EDLC fabrication.

\section{Experimental}

\subsection{Material and Preparation of Blend SPE Films}

Methyl cellulose (MC) with the average molecular weight ( $\mathrm{Mw}_{\mathrm{avg}}$ ) of $4000 \mathrm{cP}$ and polyvinyl alcohol (PVA) [purity 98\%] with the $\mathrm{Mw}_{\text {avg }}$ of 35,000 g/mol, respectively, were used as raw materials and purchased by Sigma Aldrich (Kuala Lumpur, Malaysia). Ammonium iodide $\left(\mathrm{NH}_{4} \mathrm{I}\right)$ salt (Sigma Aldrich, Kuala Lumpur, Malaysia) was used to provide $\mathrm{H}^{+}$ions in the electrolyte. The PVA:MC: $\mathrm{NH}_{4} \mathrm{I}$ electrolyte films are prepared by the raw materials using solution casting technique. For this purpose, $30 \mathrm{~mL}$ of distilled water was used to dissolve $20 \mathrm{wt}$ \% of MC at room temperature for $6 \mathrm{~h}$. At the same time, separately $80 \mathrm{wt}$ \% of PVA was dissolved in $30 \mathrm{~mL}$ of distilled water at temperature of $80^{\circ} \mathrm{C}$. When the PVA solution was cooled to room temperature, PVA and MC solutions were blended using magnetic stirrer. Consequently, $40 \mathrm{wt}$ \% of $\mathrm{NH}_{4} \mathrm{I}$ salt was added to the solution of PVA:MC blend and stirred continuously to get PVA:MC: $\mathrm{NH}_{4} \mathrm{I}$ electrolyte. To prepare plasticized PE 10 to 50 wt.\% of glycerol (Sigma Aldrich, Kuala Lumpur, Malaysia) was incorporated to the PVA: MC: $\mathrm{NH}_{4} \mathrm{I}$ electrolyte separately. The electrolytes were coded as MCPVI1, MCPVI2, MCPVI3, MCPVI4 and MCPVI5 for the PVA:MC: $\mathrm{NH}_{4} \mathrm{I}$ incorporated with $10 \mathrm{wt} . \%, 20 \mathrm{wt} . \%, 30 \mathrm{wt} . \%, 40 \mathrm{wt} . \%$ and $50 \mathrm{wt} . \%$ of glycerol plasticizer, correspondingly. Finally, the electrolyte solutions were poured into different clean and dry plastic Petri dishes, subsequently left to evaporate gradually at ambient temperature, to attain a free-standing and dry of PVA:MC: $\mathrm{NH}_{4} \mathrm{I}$ blend SPE film.

\subsection{EIS Measurements}

The measurement of impedance of the series of PEs was performed via electrical impedance spectroscopy (EIS) using HIOKI 3532-50 LCR HiTESTER (HIOKI, Nagano, Japan) (50 Hz $\leq f \leq 5 \mathrm{MHz}$ ) at ambient temperature. The impedance data was measured by inserting the PEs between two stainless steels. The analysis provided dielectric behavior and ionic conductivity of the electrolytes. The following relationship was used in calculating ionic conductivity:

$$
\sigma_{d c}=\left(\frac{1}{R_{b}}\right) \times\left(\frac{t}{A}\right)
$$

where: $t$ is the sample thickness, $A$ is the electrode area and $R_{b}$ is the bulk resistance, which is determined from the intersection of the tail with real axis [49]. 


\subsection{Linear Sweep Voltammetry (LSV) and Transference Number Measurement (TNM)}

The analysis using a linear sweep voltammetry (LSV) study enabled us to determine the breakdown voltage of an electrolyte and this explained the system electrochemical stability. The LSV was performed at a scan rate of $10 \mathrm{mV} / \mathrm{s}$ using Digi-IVY DY2300 potentiostat (Neware, Shenzhen, China). Furthermore, the ions dominancy was determined by plotting the polarization of electrolytes against time. The plot was obtained through a V\&A Instrument DP3003 (V \& A Instrument, Shanghai, China) supported with a digital DC power supply. The measurement was done with operating voltage of $0.2 \mathrm{~V}$ at room temperature.

\subsection{EDLC Preparation}

There were three primary materials to prepare the electrode in this study, which were activated carbon (Sigma Aldrich, Kuala Lumpur, Malaysia) as the active electrode material, $\mathrm{CB}$ as the electronic conductor and polyvinylidene fluoride (PVdF). $3.25 \mathrm{~g}$ of activated carbon was stirred together with $0.25 \mathrm{~g}$ of $\mathrm{CB}$ in a planetary ball miller (Neware, Shenzhen, China) at $500 \mathrm{rpm}$ for $\sim 20 \mathrm{~min}$ using six metal balls. Simultaneously, $0.5 \mathrm{~g}$ of PVdf was mixed in $15 \mathrm{~mL}$ of $\mathrm{N}$-methyl pyrrolidone (NMP) solvent (Sigma Aldrich, Kuala Lumpur, Malaysia). The mixed powders from ball miller were blended with the $\mathrm{PVdF} / \mathrm{NMP}$ solution for $2 \mathrm{~h}$ to obtain a black thick solution that was then poured onto an aluminum foil. It was dried in $60^{\circ} \mathrm{C}$ oven for a certain time to form a carbon-based electrode with high conducting characteristics. The EDLC could be fabricated at this stage in a coin cell by using the electrolyte/electrode arrangement as reported in our previous works [50]. The Galvanostatic charge-discharge (GCD) measurement was used for the synthesized EDLC cell. A Neware battery cycler (Neware, Shenzhen, China) was utilized for this measurement at a current density (J) of $0.5 \mathrm{~mA} / \mathrm{cm}^{2}$. The EDLC coin cell using the electrolyte/electrode arrangement is shown in Figure 1.

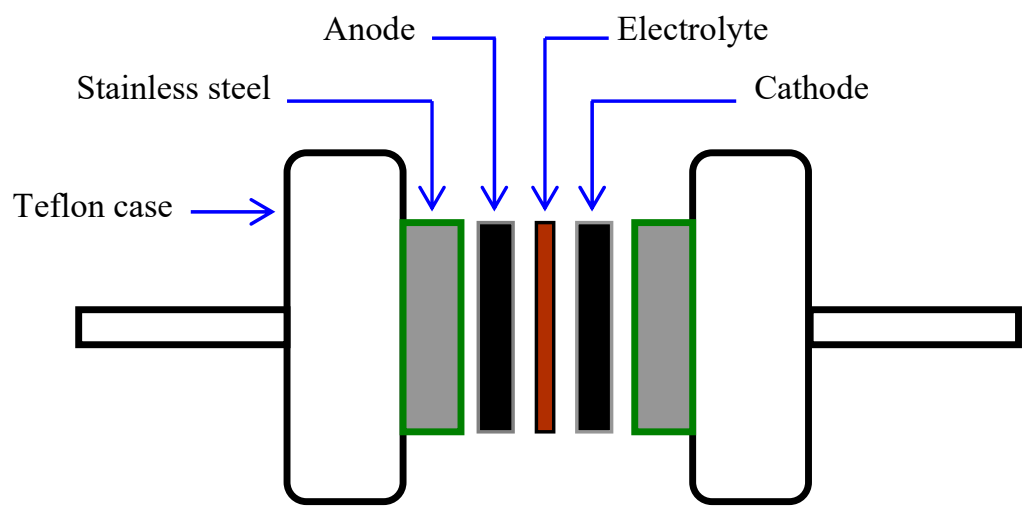

Figure 1. Diagram of the EDLC cell.

\section{Results and Discussion}

\subsection{Impedance Study}

To deal with charge transfer and ion transport, it was of great opportunity to use electric impedance spectroscopy (EIS) [51]. The Nyquist plots for all films are shown in Figure 2a-e. All plots were characterized by a tail at the low frequency region. The spike was related to creation of DL capacitance at the interfacial region [52,53]. At the low frequency region, it is assumed that a straight line is a parallel to the axis of imaginary, meaning that the straight line inclination must be $90^{\circ}$ in the EIS plots. However, the inclination of the straight line at $90^{\circ}$ resulted from the DL capacitance at the electrodes [52]. Semicircle at the high frequency region did not appeared in Figure 2a-e since most of the anions and cations at the bulk of the electrolyte (BE) transported in opposite direction, towards the stainless steel electrodes to generate the DL capacitor at the electrode-electrolyte interfaces. Different electrode materials were prepared in previous studies for SCs electrode 
application [54-56]. For example, Gomaa A. M. Ali et al. [57] synthesized $\mathrm{MoS}_{2}$ :grapheme (MSG) composite as electrode material for SCs application. They used EIS to investigate the electrochemical behavior of the MSG composite. A semicircle and a linear portion at the high and low frequency region were observed, respectively. The authors showed that the MSG composite electrode had small values of solution resistance $\left(R_{S}\right)$ of $0.76 \Omega \cdot \mathrm{cm}^{2}$ and charge transfer resistance $\left(\mathrm{R}_{\mathrm{ct}}\right)$ of $0.65 \Omega \cdot \mathrm{cm}^{2}$.Gomaa A. M. Ali et al. [58] in another study prepared activated carbon from palm kernel shell (ACPKS) and impregnated with $\mathrm{CaO}$ from egg shell ( $\mathrm{CaO} / \mathrm{ACPKS})$ as SCs electrodes. The Rs values were determined to be 2.62 and $0.92 \Omega$ for ACPKS electrode and $\mathrm{CaO} / \mathrm{ACPKS}$ electrode, respectively. The values of $R_{\mathrm{ct}}$ were determined to be 0.86 and $0.44 \Omega$ for ACPKS electrode and $\mathrm{CaO} / \mathrm{ACPKS}$ electrode, respectively.
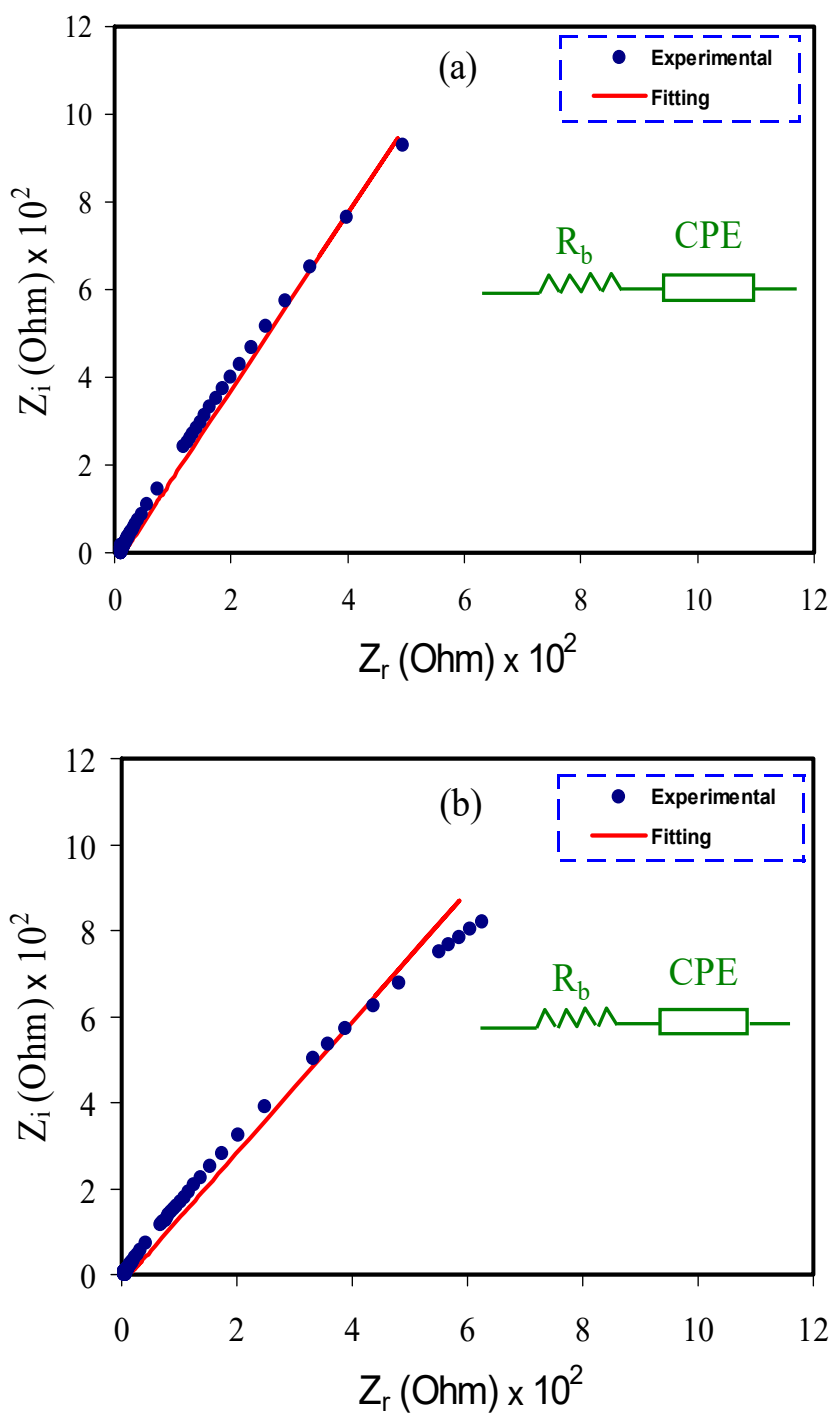

Figure 2. Cont. 

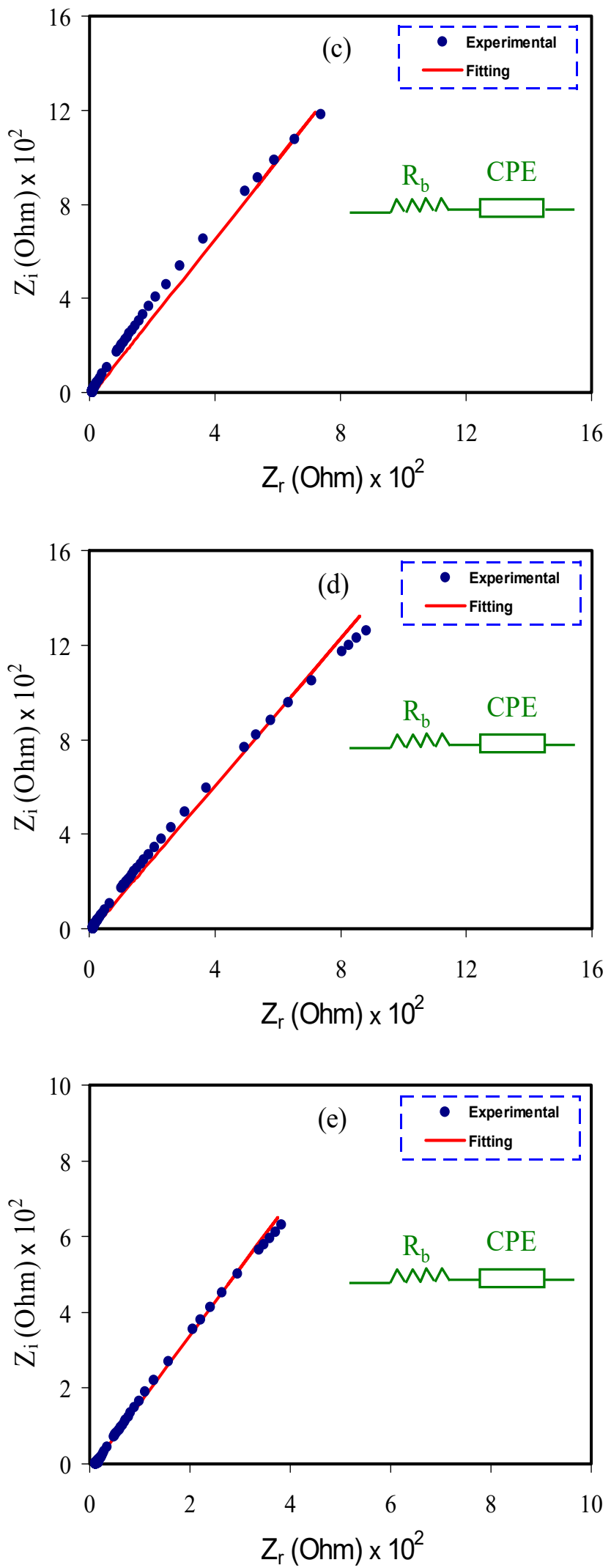

Figure 2. EIS plots for (a) MCPVI1, (b) MCPVI2, (c) MCPVI3, (d) MCPVI4 and (e) MCPVI5 electrolyte films.

Determination of the $R_{b}$ could be performed from the intercept of the spike with real axis $\left(Z_{r}\right)$ at the low frequency [59]. 
The DC conductivity was calculated easily using Equation (1). Table 1 presents the measured conductivity for all samples. It is obviously seen that the conductivity increases with increasing the plasticizer. Glycerol plasticizer (GP) has been shown to improve DC conductivity for various electrolytes by two orders of magnitude in previous studies. The multi $\mathrm{OH}$ moiety structure of glycerol serves as an alternate mechanism for free ions from salt to move in PEs. As a result, GP has a lot of $\mathrm{OH}$ groups, which allows it to dissociate more salt while also scarifying the intra and inter-hydrogen bonding in the polymer matrix, resulting in increased amorphous structures, which are essential for the ion transport process [60-62].

Table 1. DC conductivity for plasticized electrolytes at room temperature.

\begin{tabular}{cc}
\hline Designation & Conductivity $\mathbf{( S \cdot \mathbf { c m } ^ { - 1 } )}$ \\
\hline MCPVI1 & $4.12 \times 10^{-4}$ \\
MCPVI2 & $8.21 \times 10^{-4}$ \\
MCPVI3 & $1.01 \times 10^{-3}$ \\
MCPVI4 & $1.29 \times 10^{-3}$ \\
MCPVI5 & $1.80 \times 10^{-3}$ \\
\hline
\end{tabular}

To compare, the present DC conductivity is quite close to that obtained for PVA: $\mathrm{NH}_{4} \mathrm{SCN}$ :Ce(III)-complex:glycerol composite PE $\left(\sigma_{d c}=2.07 \times 10^{-3} \mathrm{~S} / \mathrm{cm}\right)$ recorded by Brza et al. [2]. Gel PEs generally possess larger ionic conductivity than SPEs without safety concerns of liquid electrolytes [63]. The ionic conductivity in this work is comparable to that obtained by Zhao et al. [64] who prepared stretchable SCs device composed of highly stretchable gel electrolyte and polypyrrole electrodes materials. The gel PE in their study has shown the DC conductivity of $3.4 \times 10^{-3} \mathrm{~S} \mathrm{~cm}^{-1}$ for PVA $/ \mathrm{H}_{3} \mathrm{PO}_{4}$. The acceptable level of DC conductivity of the electrolyte is in the range between $10^{-3}$ to $10^{-5}$ in order for the electrolyte to be used for application in electrochemical devices and industry [65-67].

To investigate the EIS of each electrolyte, it is easy to use the electrical equivalent circuit (EEC) model [68]. From the Nyquist plots and modeling the EEC of the electrolytes, a constant phase element, i.e., CPE and the $R_{b}$ for the carriers are achieved as indicated in the Figure $2 \mathrm{a}-\mathrm{e}$ inset. The fitting parameters of EEC are indicated in Table 2. The $Z_{C P E}$ is expressed as follow [31]:

$$
Z_{C P E}=\frac{\cos (\pi n / 2)}{C \omega^{n}}-j \frac{\sin (\pi n / 2)}{C \omega^{n}}
$$

where the CPE capacitance is symbolized as $C$, the angular frequency is assigned as $\omega$ and $n$ is associated to the imaginary axis deviation of the Nyquist plot. It is established that the Nyquist plot shows that the just the resistive component of the electrolyte is dominated. The polymer can also behave like an insulator and the CPE and $R_{b}$ are connected together in series as revealed in the Figure $2 \mathrm{a}-\mathrm{e}$ inset. The semicircle disappearance in the electrolyte systems is because most of the anions and cations in the BE transfer to the surface of the electrodes to generate the DL. In this case, the values of $Z_{r}$ and $Z_{i}$ of the EEC can mathematically be shown as follow [31]:

$$
\begin{gathered}
Z_{r}=R+\frac{\cos (\pi n / 2)}{C \omega^{n}} \\
Z_{i}=\frac{\sin (\pi n / 2)}{C \omega^{n}}
\end{gathered}
$$


Table 2. The EEC fitting parameters for plasticized electrolyte systems at room temperature.

\begin{tabular}{|c|c|c|c|c|}
\hline Sample & $n$ (rad) & $K\left(\mathrm{~F}^{-1}\right)$ & $R_{b}(\Omega)$ & CPE (F) \\
\hline MCPVI1 & 0.706 & $6.13 \times 10^{4}$ & $\begin{array}{c}(0.16 \pm 0.060) \times \\
10^{2}\end{array}$ & $\begin{array}{c}(1.63 \pm 0.58) \times \\
10^{-5}\end{array}$ \\
\hline MCPVI2 & 0.63 & $6.125 \times 10^{4}$ & $\begin{array}{c}(0.14 \pm 0.061) \times \\
10^{2}\end{array}$ & $\begin{array}{c}(1.633 \pm 0.60) \times \\
10^{-5}\end{array}$ \\
\hline MCPVI3 & 0.658 & $6.12 \times 10^{4}$ & $\begin{array}{c}(0.13 \pm 0.062) \times \\
10^{2}\end{array}$ & $\begin{array}{c}(1.634 \pm 0.61) \times \\
10^{-5}\end{array}$ \\
\hline MCPVI4 & 0.636 & $6.11 \times 10^{4}$ & $\begin{array}{c}(0.12 \pm 0.061) \times \\
10^{2}\end{array}$ & $\begin{array}{c}(1.64 \pm 0.60) \times \\
10^{-5}\end{array}$ \\
\hline MCPVI5 & 0.674 & $3.61 \times 10^{4}$ & $\begin{array}{c}(0.105 \pm 0.059) \\
\times 10^{2}\end{array}$ & $\begin{array}{c}(2.77 \pm 0.68) \times \\
10^{-5}\end{array}$ \\
\hline
\end{tabular}

In Table $2, K$ is the reciprocal of capacitance at the low frequency region.

As the Nyquist plot plot consists of a spike only, the mobility $(\mu)$, diffusion coefficient $(D)$ and number density $(n)$ of ions are determined using the below relations [2]:

The $D$ of the ions of each system is determined using the relation:

$$
D=D \circ \exp \left\{-0.0297\left[\ln D_{\circ}\right]^{2}-1.4348 \ln D \circ-14.504\right\}
$$

where:

$$
D \circ=\left(\frac{4 k^{2} l^{2}}{R_{b}{ }^{4} \omega_{\min ^{3}}}\right)
$$

where $l$ is the film thickness and $\omega_{\min }$ refers the angular frequency corresponding to the lowest value of $Z_{i}$.

The mobility $(\mu)$ of the ions is determined using Equation (7):

$$
\mu=\left(\frac{e D}{K_{b} T}\right)
$$

where $k_{b}$ and $T$ refer the Boltzmann constant and the absolute temperature, respectively.

Since conductivity of carriers is determined by:

$$
\sigma_{D c}=n e \mu
$$

Thus, the $n$ of ions is determined using Equation (8):

Table 3 reveals the $\omega_{\min }$ values and the transport parameter values for each electrolyte system.

Table 3. The $\omega, \mu, D$ and $n$ values at room temperature.

\begin{tabular}{ccccc}
\hline Sample & $\boldsymbol{\omega}\left(\mathbf{r a d ~ s}^{-\mathbf{1}}\right)$ & $\boldsymbol{D}\left(\mathbf{c m}^{\mathbf{2}} \mathbf{s}^{-\mathbf{1}}\right)$ & $\left.\boldsymbol{\mu} \mathbf{( c m}^{\mathbf{2}} \mathbf{V}^{-\mathbf{1}} \mathbf{s}\right)$ & $\boldsymbol{n} \mathbf{( \mathbf { c m } ^ { - 3 } )}$ \\
\hline MCPVI1 & $2.20 \times 10^{5}$ & $1.59 \times 10^{-6}$ & $6.20 \times 10^{-5}$ & $4.15 \times 10^{19}$ \\
MCPVI2 & $7.54 \times 10^{4}$ & $2.39 \times 10^{-6}$ & $9.32 \times 10^{-5}$ & $5.50 \times 10^{19}$ \\
MCPVI3 & $1.63 \times 10^{5}$ & $2.42 \times 10^{-6}$ & $9.45 \times 10^{-5}$ & $6.67 \times 10^{19}$ \\
MCPVI4 & $1.26 \times 10^{5}$ & $2.43 \times 10^{-6}$ & $9.48 \times 10^{-5}$ & $8.49 \times 10^{19}$ \\
MCPVI5 & $1.30 \times 10^{5}$ & $2.44 \times 10^{-6}$ & $9.51 \times 10^{-5}$ & $1.18 \times 10^{20}$ \\
\hline
\end{tabular}

On the basis of Table 3, the $D$ value was increased when the glycerol increased from 10 to $50 \mathrm{wt} . \%$. As seen in Table $3 \mu$ showed the same trend where $\mu$ increased. The improvement of $D$ and $\mu$ is associated to the chain flexibility development by the adding of glycerol. When more glycerol was added, the $\mu, D$ and $n$ improved which caused enhanced conductivity because the addition of more glycerol dissociated extra salts to cations and anions, thus improving the $n$ of carriers [2]. Glycerol reduces the attraction force between the anions and cations of the salt [69]. Hence, a higher number of ammonium ions $\left(n_{i}\right)$ is generated by $\mathrm{NH}_{4} \mathrm{I}$ to the polymer. It was documented that [69] the dielectric constant of 
electrolytes increased with decreasing frequency and thus the capacitance would increase. The capacitance is also increased with increasing the glycerol concentration. The plasticizer to the electrolyte increased the number density of free ions (see Table 3), and hence increased the dielectric constant value as mentioned at the next section.

It is observed in Figure 3a that the MCPVI1 film has the largest charge transfer resistance $\left(R_{c t}=2.56 \Omega\right)$. Obviously, with rising concentration of glycerol, as revealed in Figure $2 \mathrm{~b}-\mathrm{e}$, the $\mathrm{R}_{\mathrm{ct}}$ decreased to $0.76 \Omega$. The dispersion region at the low-frequency region in the Bode plots is ascribed to the diffusion of ions phenomenon and the high-frequency region is attributed to the $R_{\mathrm{ct}}$ [70]. In Figures 2 and 3, it is shown that the MCPVI5 film has the minimum $R_{\mathrm{ct}}$ and, thus, a higher DC conductivity was obtained. Thus, the Bode plot agreed with the results achieved from the EIS plots. From a physics viewpoint, it is vital to fabricate PE with higher conductivity, while it is vital for the films to show a low $R_{\mathrm{ct}}$ from a chemistry viewpoint [70].
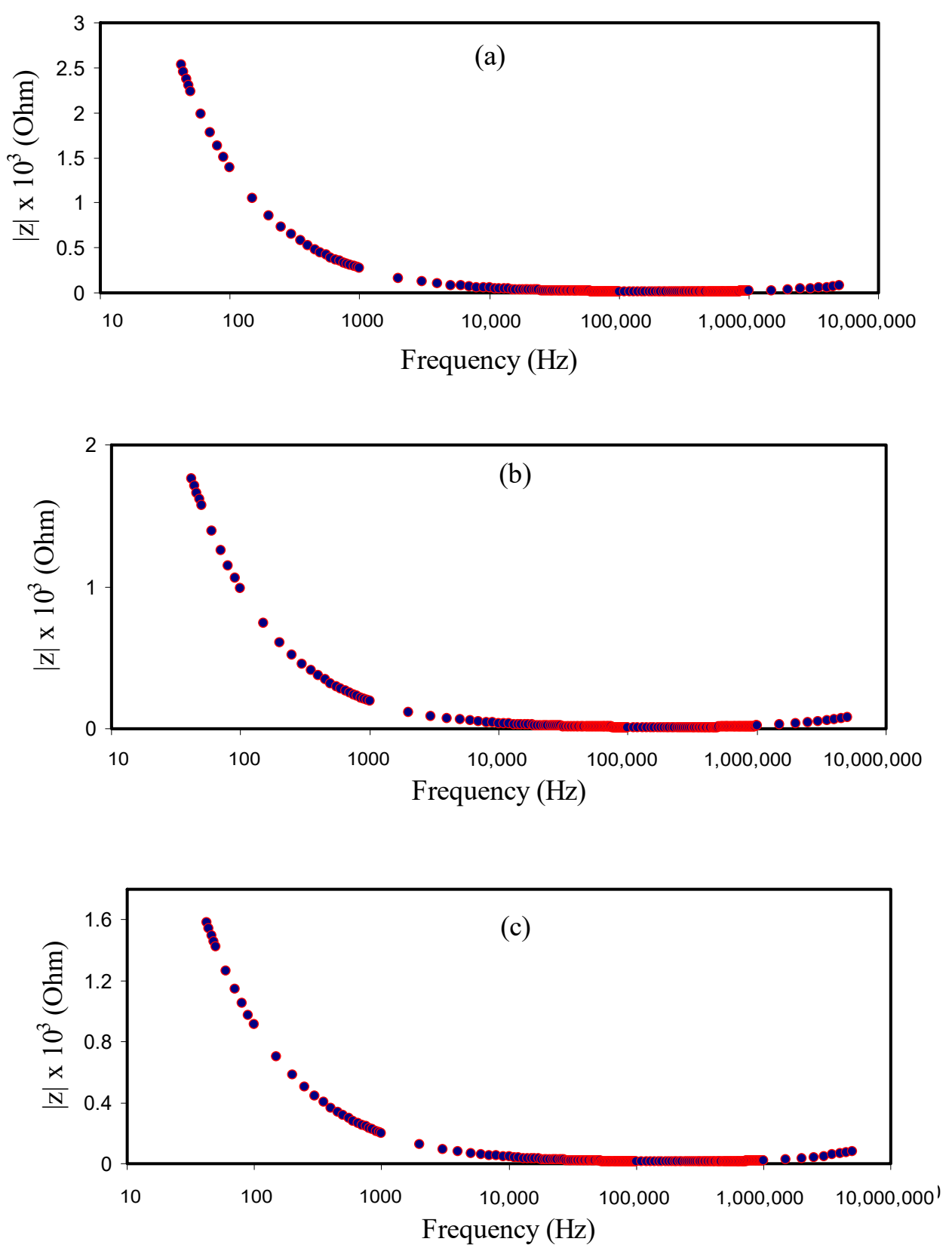

Figure 3. Cont. 

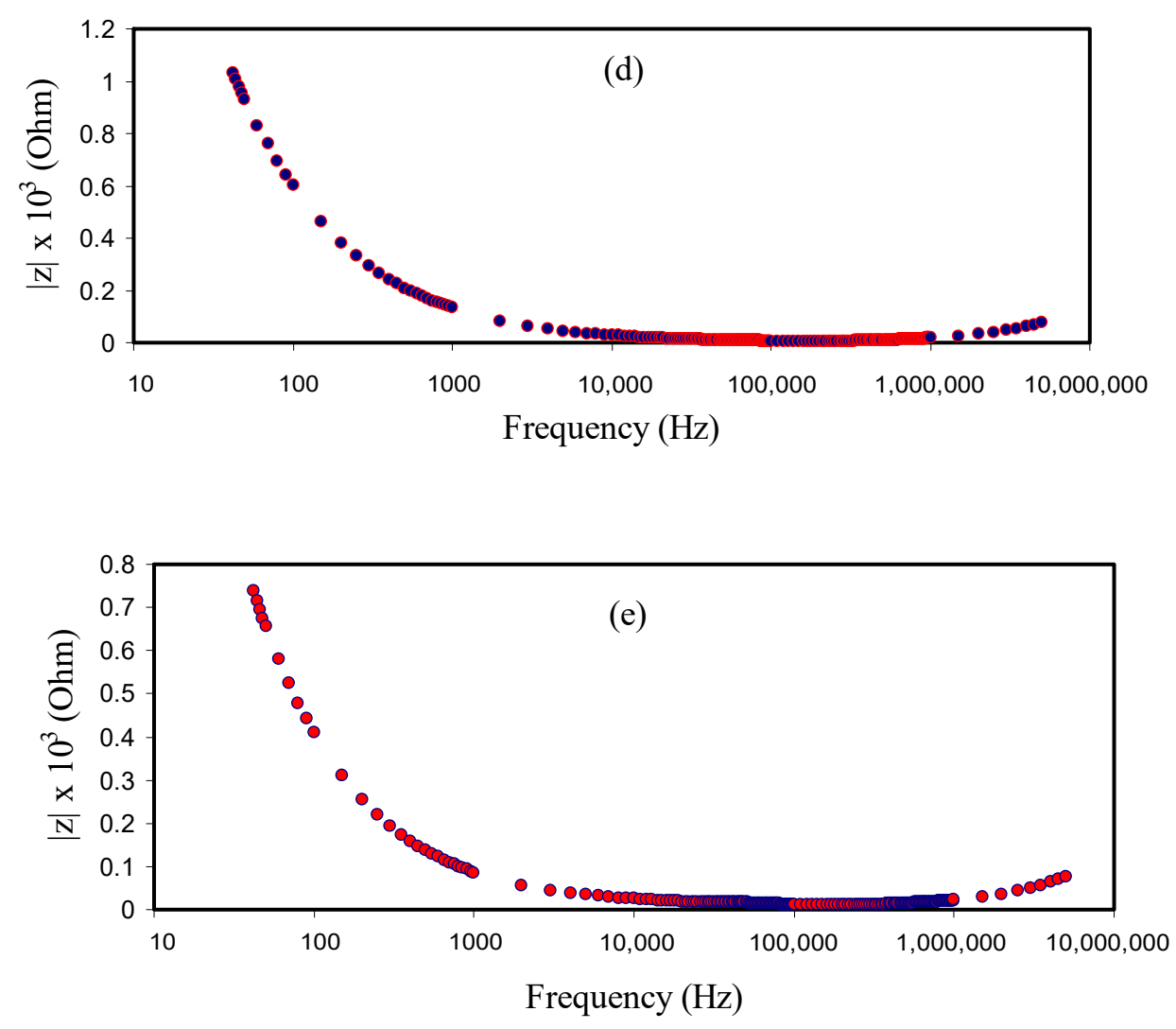

Figure 3. Bode plots for (a) MCPVI11, (b) MCPVI2, (c) MCPVI3, (d) MCPVI4 and (e) MCPVI5 electrolyte films.

\subsection{Dielectric Properties}

It has been emphasized that understanding and recognizing charge carrier transport mechanisms in electrolytes can be achieved via studying dielectric properties [71,72]. The dielectric loss $\left(\varepsilon_{\mathrm{i}}\right)$ and dielectric constant $\left(\varepsilon_{\mathrm{r}}\right)$ are frequency dependents that can be calculated using the equations as reported in reference [73].

The $\varepsilon_{\mathrm{r}}$ and $\varepsilon_{\mathrm{i}}$ parameters versus frequency upon quantity of plasticizer are shown in Figures 4 and 5, respectively, at ambient temperature. The dielectric response exhibits a dispersion region that declined with rising frequency in all samples.

This can be explained on the basis of providing adequate time for charge carriers and dipoles to alter the direction when an electric field is applied at low frequency. As a consequence, building up of large number of charge carrier occurs at the interfacial region accompanied with electrode polarization. This phenomenon results in suppression of dielectric properties at high frequency range [74]. It is also noted that the space-charge disappears at the high-frequency region as a result of prohibition of dipole moment and charge carrier to flow at high periodic reversal form of the applied external AC electric field. Moreover, under this condition there is no ion moving from BE into diffuse layer at the interfacial region. Thus, the dielectric parameters $\left(\varepsilon_{\mathrm{r}}\right.$ and $\left.\varepsilon_{\mathrm{i}}\right)$ decrease gradually as the frequency increases [75,76].

This study has shown that dielectric properties of the PE are highest with incorporation of $50 \mathrm{wt} . \%$ of glycerol. This indicates the existence of a large number of charge carrier and thus relatively high conductivity [77]. 


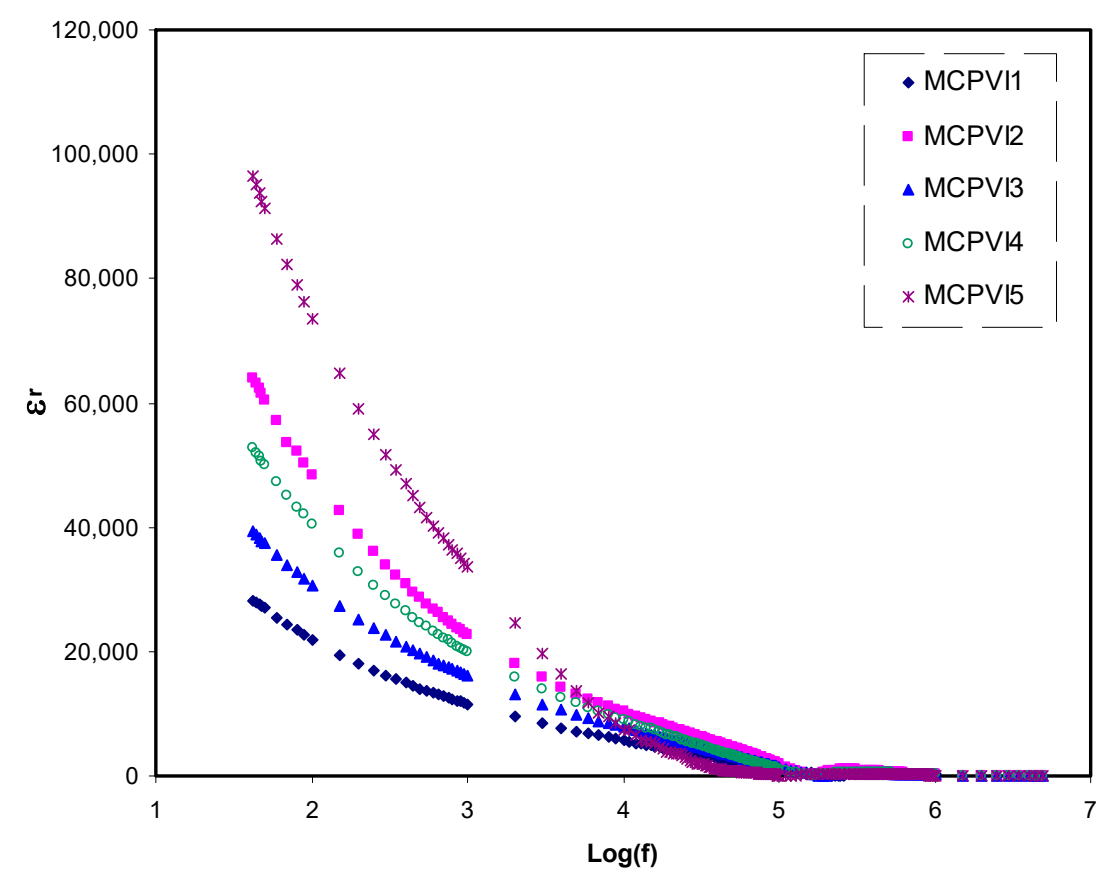

Figure 4. Dielectric constant $\left(\varepsilon^{\prime}\right)$ spectra versus frequency for the prepared samples.

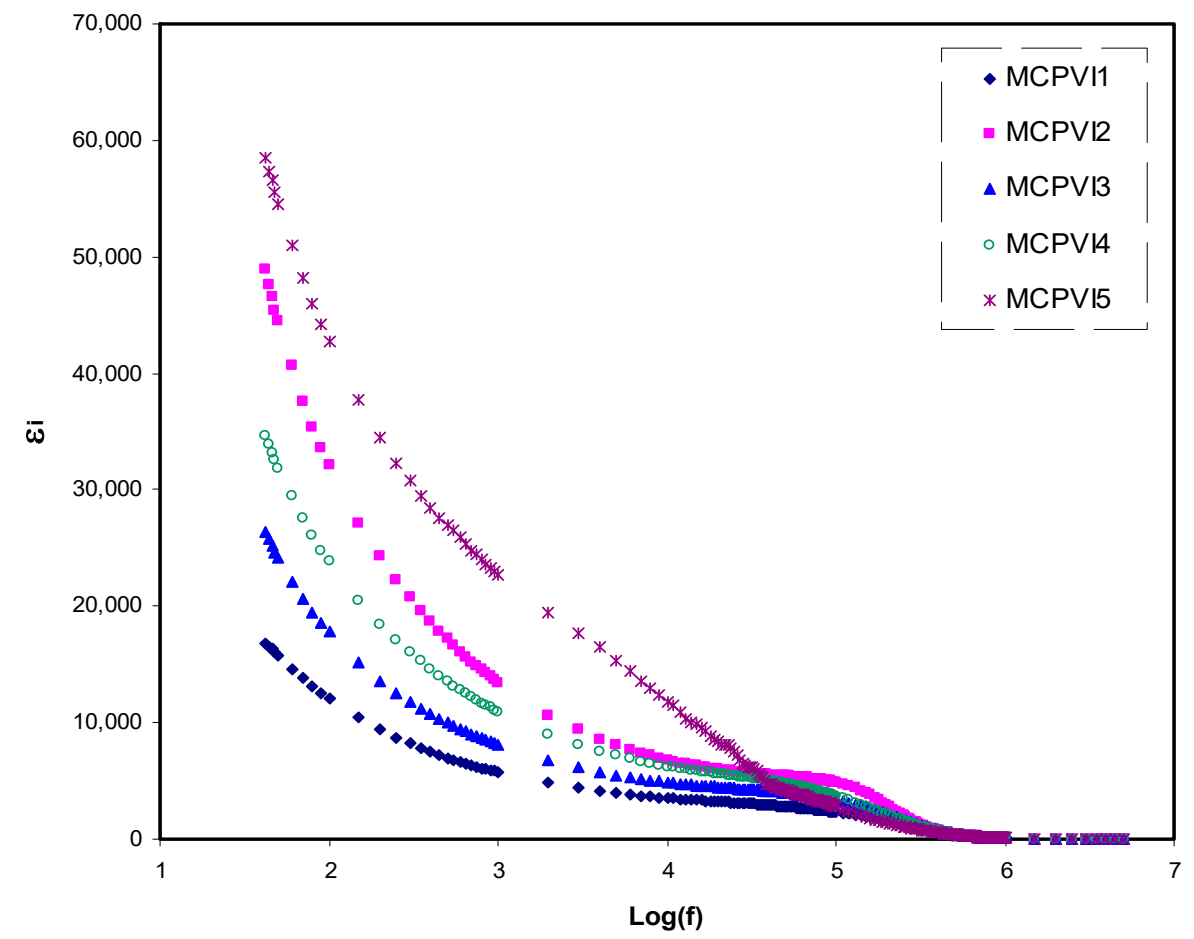

Figure 5. Dielectric loss $\left(\varepsilon^{\prime \prime}\right)$ spectra versus frequency for the prepared samples.

\subsection{Transference Number Measurement (TNM) and Linear Sweep Voltammetry (LSV) Studies}

The suitability of a PE for the application of a common EDLC function can be identified through both TNM and LSV analyses [50]. There are two types of charge carriers present in a typical PE system which are ions and electrons, and the major conducting components in an electrolyte will be revealed by these studies. Figures 6 and 7 show the TNM plots for the PVA:MC: $\mathrm{NH}_{4} \mathrm{I}$ electrolyte with the addition of $40 \mathrm{wt} . \%$ and $50 \mathrm{wt} \%$ glycerol, respectively. 


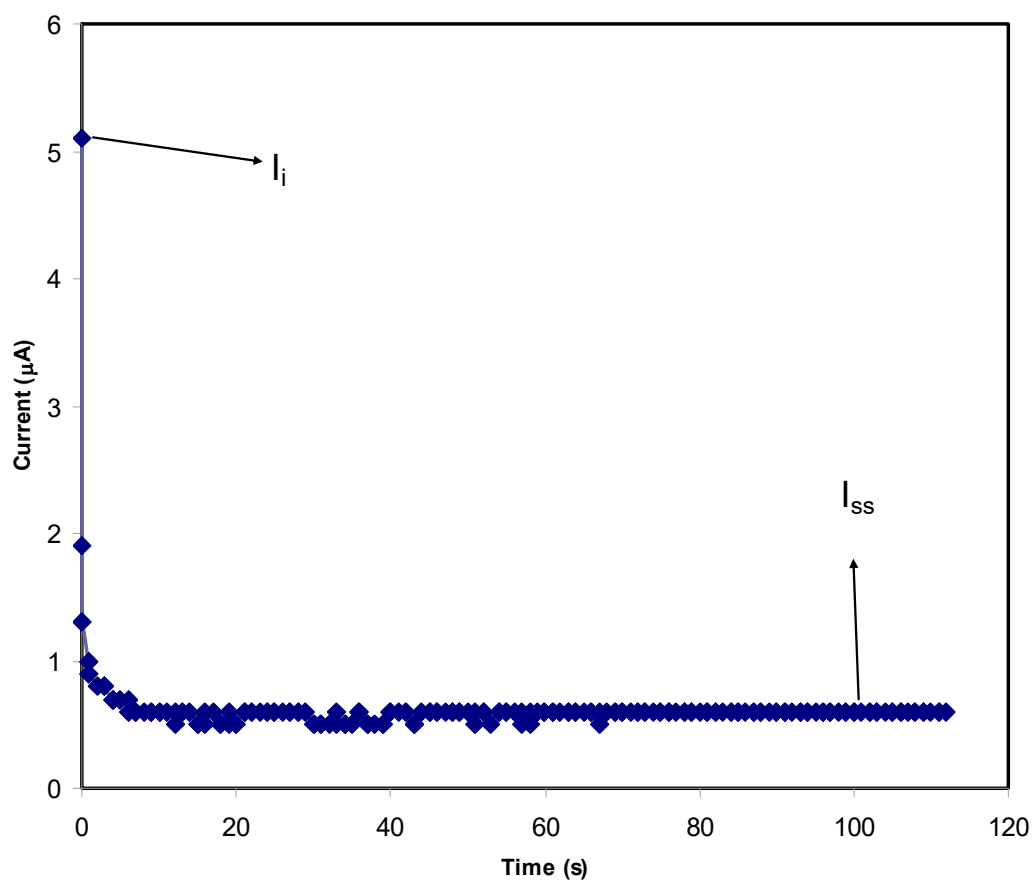

Figure 6. TNM plot for PVA:MC: $\mathrm{NH}_{4} \mathrm{I}$ electrolyte with $40 \mathrm{wt} . \%$ glycerol.

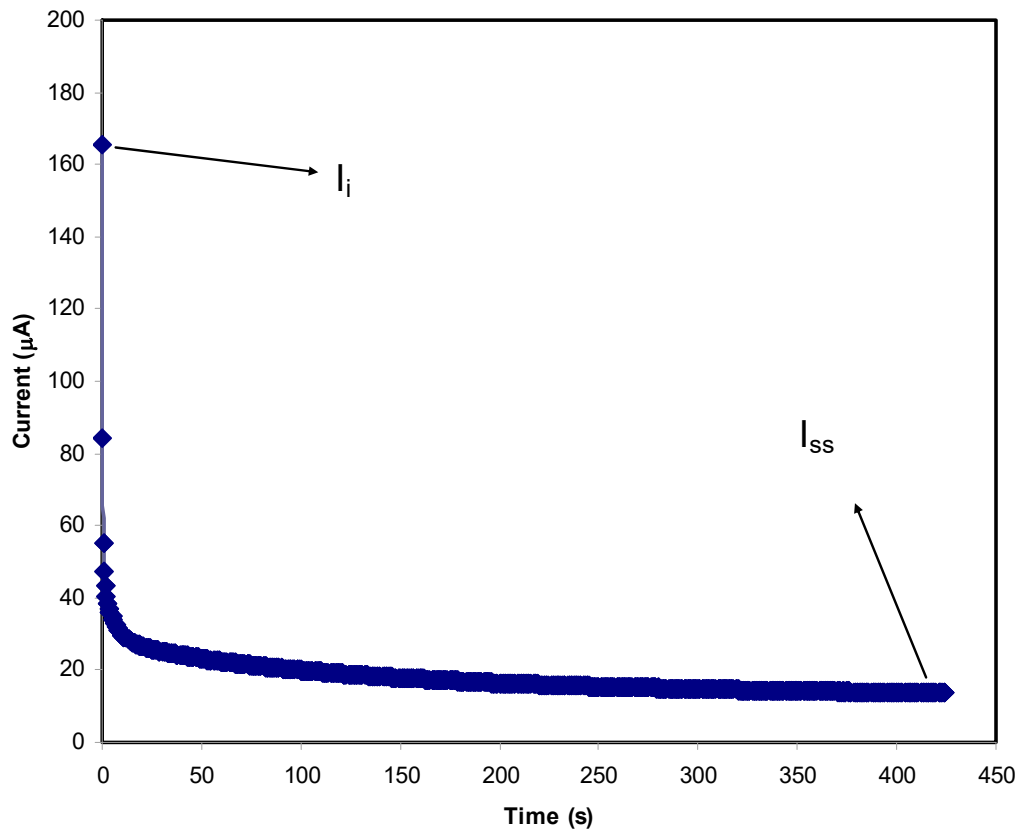

Figure 7. The TNM plot for PVA:MC:NH${ }_{4} \mathrm{I}$ electrolyte with $50 \mathrm{wt} . \%$ glycerol.

The polarization processes in Figures 6 and 7 show that the initial current $\left(I_{i}\right)$ for the PVA:MC: $\mathrm{NH}_{4} \mathrm{I}$ electrolyte with $50 \mathrm{wt} . \%$ glycerol is higher than the electrolyte with $40 \mathrm{wt} . \%$ glycerol concentration. This difference exhibits the effect of plasticizer to the amount of conduction species in the electrolyte. However, both electrolytes achieved high initial current which is contributed by ions and electrons. Then, a drastic current drop is observed for both plots due to the blocking of ions caused by the characteristics of the stainless steel electrode. The electrode only allows the electrons to move. The current decay region is where the ions' diffusion process is equivalent to ions' drifting within a short time period. The polarization happens for a long time period at the steady state because of the diffusion layer development on the interface's region. Additionally, this phenomenon is also dealing 
with the high resistance of the formation of the passive layer by ions, thus the current flow is totally caused by the electrons without the involvement of ions [50]. Based on the plots, the electrolyte with a high concentration of glycerol is observed to require longer time for the current to reach steady state $\left(I_{S S}\right)$ as the low concentration requires less time. By using the Equations (9) and (10), the value of the electronic $\left(t_{\text {elec }}\right)$ and ionic $\left(t_{\text {ion }}\right)$ transference numbers can be determined and tabulated in Table 4.

$$
\begin{aligned}
& t_{\text {ion }}=\frac{I_{i}-I_{\text {sS }}}{I_{i}} \\
& t_{\text {elec }}=1-t_{\text {ion }}
\end{aligned}
$$

Table 4. Transference number for PVA:MC: $\mathrm{NH}_{4} \mathrm{I}:$ Gly electrolytes.

\begin{tabular}{ccc}
\hline Glycerol (wt.\%) & $\boldsymbol{t}_{\text {elec }}$ & $\boldsymbol{t}_{\text {ion }}$ \\
\hline 40 & 0.118 & 0.882 \\
50 & 0.083 & 0.917 \\
\hline
\end{tabular}

According to the Table 4, it was discovered that both electrolytes achieved high $t_{i o n}$ values which led to an explanation that both systems are dominantly contributed by the ions to serve as the conducting element [78]. The addition of $50 \mathrm{wt}$. $\%$ glycerol into PVA:MC: $\mathrm{NH}_{4} \mathrm{I}$ electrolyte caused the $t_{\text {ion }}$ to be higher at 0.917 with $t_{\text {elec }}$ value of 0.083 compared to $40 \mathrm{wt}$.\% glycerol electrolyte. The result obtained from this analysis verifies that the addition of $50 \mathrm{wt}$ \% glycerol into PVA:MC: $\mathrm{NH}_{4} \mathrm{I}$ electrolyte can produce a highly ion contributing electrolyte that is fits to be applied in EDLC where the electromotive force will be occurred between carbon electrodes and ions $[79,80]$. High $t_{i o n}$ value was also reported by Shukur et al. [42] for the plasticized electrolyte based on the chitosan- $\mathrm{NH}_{4} \mathrm{Br}$ polymer blend and the electrolyte showed a promising performance in the EDLC application.

The working potential range is one of the critical characteristics that needs to be verified because it will determine the breakdown voltage of the electrolyte. LSV analysis was carried out at room temperature for the PVA:MC: $\mathrm{NH}_{4} \mathrm{I}$ :Gly electrolyte with the highest conductivity value as illustrated in Figure 8. Based on the plot, it was observed that no obvious J was recorded through the applied voltage from 0 to $1.625 \mathrm{~V}$. According to Sampathkumar et al. [81], no electrochemical reaction occurs within the electrolyte at this region. However, when the voltage increased more than $1.65 \mathrm{~V}$, the J started to gradually increase which correlated to the breakdown point of electrolyte and also indicated the occurrence of electrochemical reaction [82]. A comparable LSV result was reported by Asnawi et al. [83] for the plasticized chitosan- $\mathrm{NH}_{4} \mathrm{~F}$ electrolyte system. For the fabrication of energy devices, the minimum breakdown voltage is $1.0 \mathrm{~V}$ and the electrolyte in this work shows a promising stability, hence it is suitable to be applied in a common EDLC application [84]. Bockenfeld et al. [85] utilized protic ionic liquid electrolyte for a lithium ion battery. They showed that the electrolyte $0.5 \mathrm{M}$ lithium nitrate $\left(\mathrm{LiNO}_{3}\right)$ in propylene carbonate (PC)-pyrrolidinium nitrate $\left(\mathrm{PYRNO}_{3}\right)$ showed the total potential stability of 2.65 V. G A M Ali et al. [86] prepared carbon nanospheres (NSs) by seeds of lablab purpureus and they revealed that the carbon NSs materials are valuable in applications of SCs electrode. The authors indicated that the practical symmetrical SCs has a good electrochemical behavior under potentials window up to $1.7 \mathrm{~V}$. 


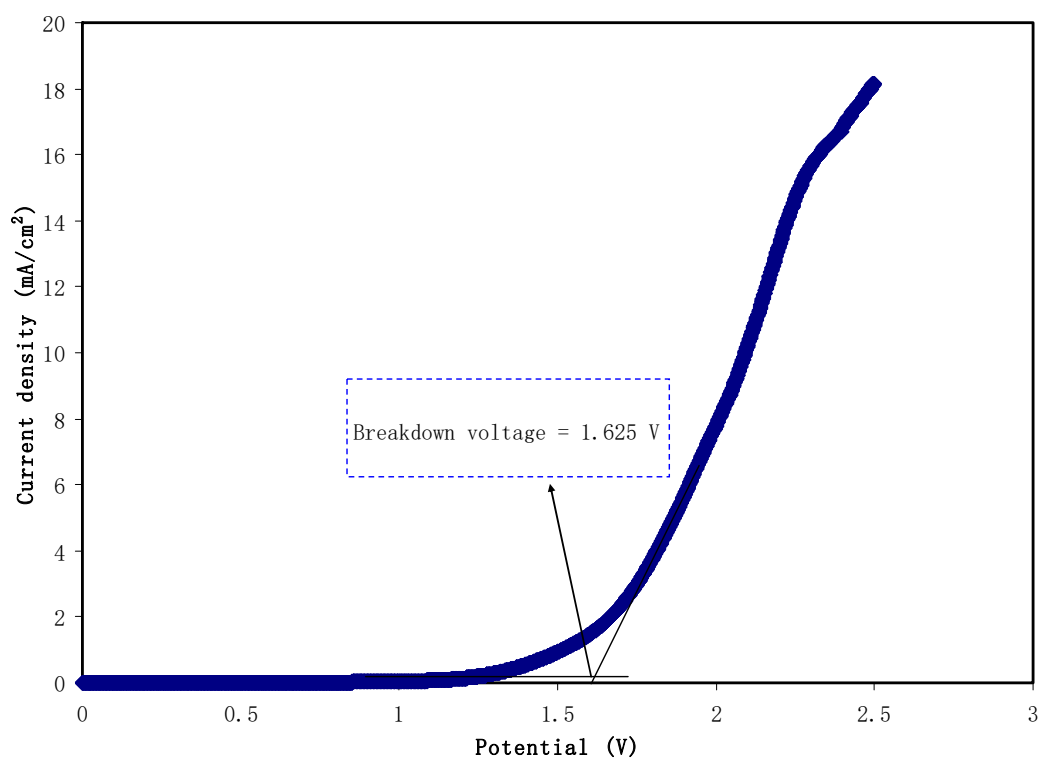

Figure 8. The LSV of the highest conducting PVA:MC:NH $4 \mathrm{I}: G l y$ electrolyte at room temperature.

\subsection{Characterization of EDLC}

The Galvanostatic charge-discharge (GCD) measurement had been used to evaluate the performance of EDLC as well as revealing few significant properties such as equivalent series resistance and specific capacitance. The GCD plot of the fabricated EDLC using the highest conducting PVA:MC: $\mathrm{NH}_{4} \mathrm{I}$ :Gly electrolyte is depicted in Figure 9 for selected cycles. Additionally, the linear discharge slope indicates the capacitive behavior of the EDLC that might be caused by the ionic DL at the electrode/electrolyte region [43]. A small voltage drop, $V_{\text {drop }}$ is obtained by the GCD. As stated by Farah et al. [87], the occurrence of $V_{\text {drop }}$-also called ohmic loss-is due to the internal resistance such as electrolyte's bulk resistance and charge transfer resistance which are produced between the electrode and electrolyte interface area within the EDLC. As the cycle number is increased, the $V_{d r o p}$ value tends to increase because of the mobile ions' reduction due to their accumulation and migration at the DL region [88].

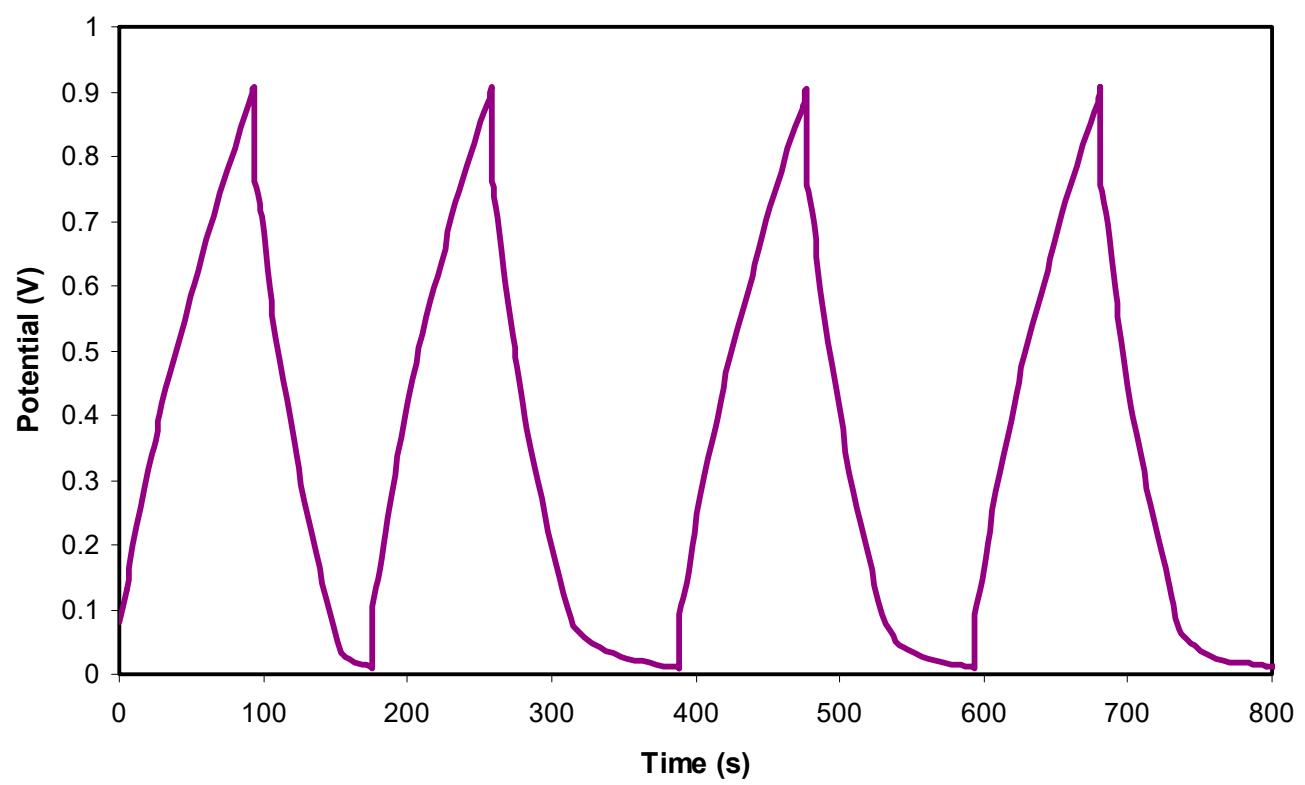

Figure 9. Galvanostatic charge-discharge plot of the fabricated EDLC for selected cycle. 
The internal resistance, also known as equivalent series resistance (ESR) that exists due to the presents of $V_{d r o p}$ can be expressed using the Equation (11):

$$
E S R=\frac{V_{d r o p}}{i}
$$

where $i$ represents the operation current.

The calculated value of ESR for 200 cycles can be observed in Figure 10. The first cycle of EDLC shows the ESR value of $110 \mathrm{Ohm}$ and then a gradually increment of ESR can be noticed throughout the cycles; $160 \mathrm{Ohm}$ at the 40 th cycle and $240 \mathrm{Ohm}$ at the final cycle. Various factors have been reported to cause the existence of ESR, where the first one is due to the current collectors used for the fabrication which are aluminum foil. Next, the rapid charge-discharge within the electrolyte will cause the free ions to recombine and lead to the decrement of ionic conductivity. Kang et al. [89] agreed that ESR was strongly related to the conductivity of an electrolyte. Additionally, the DL charge is established by the activities at the space between electrode/electrolyte which are movements of electrons and ions [90]. Wang et al. [91] studied the EDLC using starch-lithium acetate system and exhibited a similar trend as in this work where ESR increased while the $C_{S}$ values were maintained at an approximate constant value.

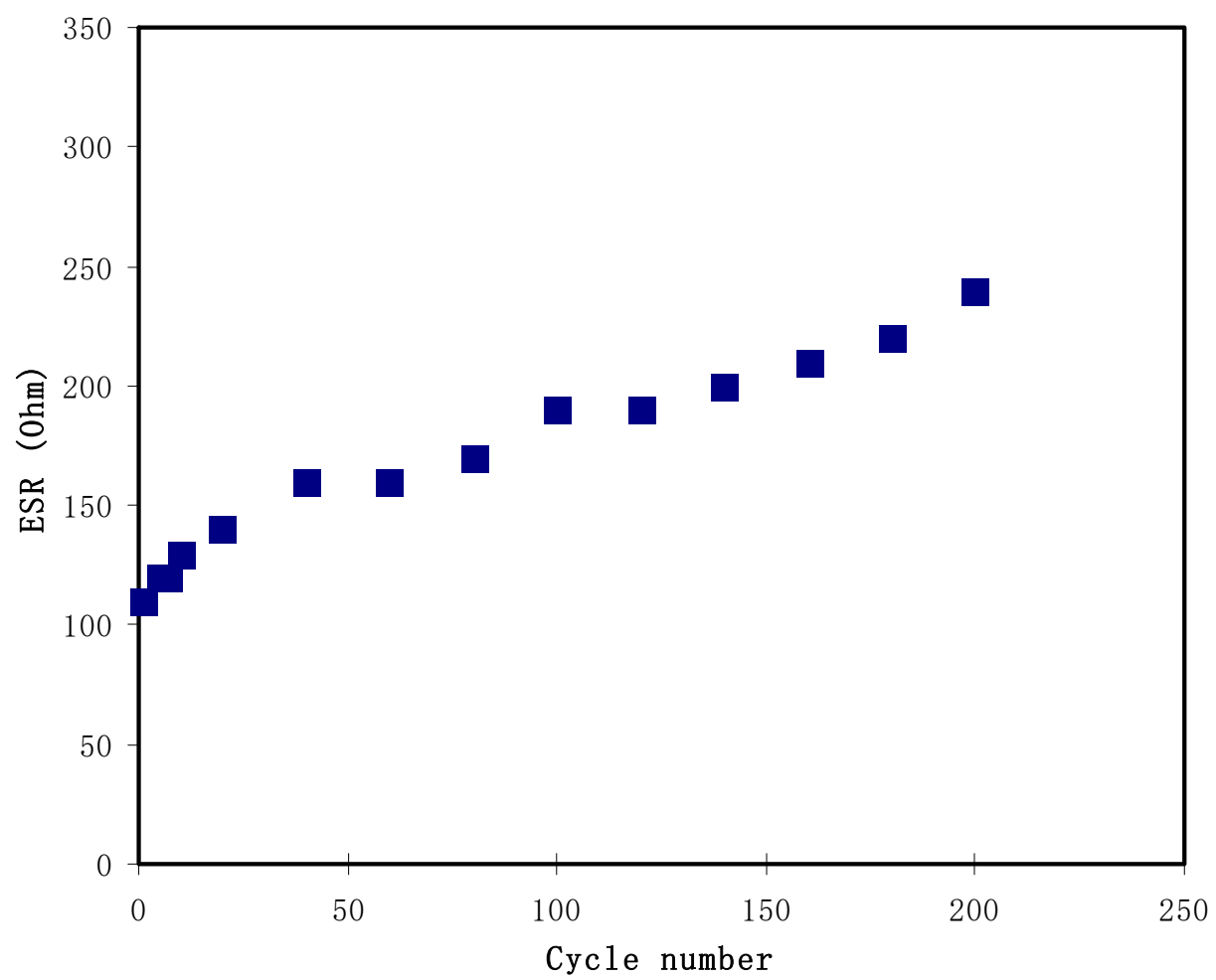

Figure 10. The equivalent series resistance, ESR from GCD plot for 200 cycles.

The specific capacitance $\left(C_{S}\right)$ had been measured using the equations as reported in references [92-94]. The mass of activated carbon used for the calculation is $2.43 \times 10^{-3} \mathrm{~g}$. The determined $C_{S}$ values are plotted in the Figure 11 for 200 cycles. The calculated $C_{S}$ value is achieved by the fabricated EDLC is $47.85 \mathrm{~F} / \mathrm{g}$ at the first cycle. Then, the $C_{S}$ value lowers to $36.10 \mathrm{~F} / \mathrm{g}$ when the cycle number increases to 40 and the values then start to stay at approximately $35.48 \mathrm{~F} / \mathrm{g}$ until the $200 \mathrm{th}$ cycle. The reduction of $C_{S}$ values might be caused by the weak contact at electrode/electrolyte region $[95,96]$. The almost constant values achieved at the end of cycle number are because the electrolyte is slowly polarized, and the accumulation of charge occurred on both electrodes; this whole process is called the stabilization of ion polarization [66]. Azli et al. [97] has reported comparable $C_{s}$ values 
calculated based on GCD plot by using similar activated carbon electrodes. G A M Ali et al. [98] synthesized porous nanocarbons (NCs) using bio-waste oil palm leaf. The NCs indicated good SCs property. They reported a high specific capacitance of $368 \mathrm{~F} / \mathrm{g}$ at 0.06 $\mathrm{A} / \mathrm{g}$ in $5 \mathrm{M} \mathrm{KOH}$. Low resistance values were achieved in their study indicating the porous NCs availability as precursor in the creation of SCs electrodes. In another study, G A M Ali et al. [86] created carbon NSs by lablab purpureus seed. The authors documented that the carbon NSs were useful for electrode applications in SCs. The specific capacitances in their study were determined to be 300,265 and $175 \mathrm{~F} \mathrm{~g}^{-1}$ in $5 \mathrm{M} \mathrm{KOH}$ electrolyte for carbon NSs prepared at 800,700 and $500{ }^{\circ} \mathrm{C}$, respectively.

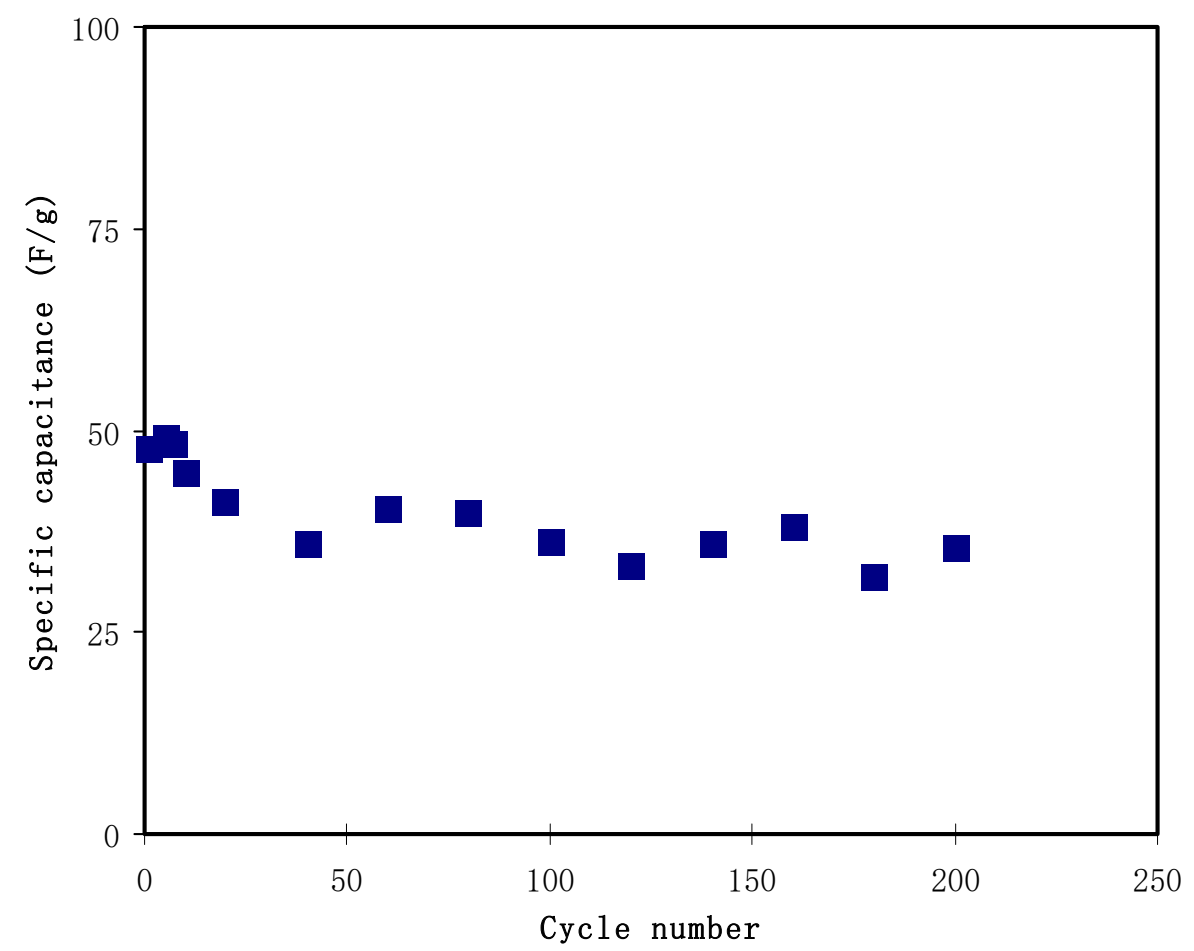

Figure 11. The specific capacitance, $C_{s}$ from GCD plot for 200 cycles.

Minakshi et al. [99] showed that the ES of sodium and lithium ions from aqueous solution in binary metal oxide (BMO) was important for uses of renewable ES. They mentioned the $\mathrm{BMO}$ as a novel electrode material for SCs. They showed that the binary metal oxide of $\mathrm{CaMoO}_{4}$ in salt-in-water $\mathrm{NaOH}$ at $0.5 \mathrm{~A} \mathrm{~g}^{-1}$ had a specific capacitance of $206 \mathrm{~F} / \mathrm{g}$. Biswal et al. [100] prepared hierarchical porous cobalt (CO)-nickel (Ni)-iron $(\mathrm{Fe})$ ternary oxide heterostructure (HS) as an electrode material for application in hybrid capacitors due to their large redox potentials. The authors examined role of concentration of Fe in ternary oxide HS as ES material on the hybrid device. They showed that the increasing Fe concentration in the metal oxide reduced the specific capacitance from $440 \mathrm{~F} / \mathrm{g}$ to $272 \mathrm{~F} / \mathrm{g}$, representing a large difference in the observed redox mechanisms.

It is also important to identify the energy density $\left(E_{d}\right)$ and power density $\left(P_{d}\right)$ of the fabricated EDLC which has been calculated using the equations as reported in references [15]. Figure 12 shows the $E_{d}$ and $P_{d}$ of the fabricated EDLC for 200 cycles. The $E_{d}$ plot is noticed to be in a good agreement with the $C_{s}$ plot. The calculated $E_{d}$ for the first cycle of the EDLC was $5.38 \mathrm{Wh} / \mathrm{kg}$ and dropped to $4.63 \mathrm{Wh} / \mathrm{kg}$ at cycle number 20 . The values were found to stabilize between 4.54 to $3.59 \mathrm{Wh} / \mathrm{kg}$ from the 60th cycle towards the end. These stabilize readings were caused by the amount of energy required for the movements of ions from the BE towards the electrode's surface which was almost similar [101]. Furthermore, the $P_{d}$ plot is also depicted in Figure 12. Along the 200 cycles of charge-discharge, $P_{d}$ values of the EDLC experienced a step-by-step drop from 757.58 to $347.22 \mathrm{~W} / \mathrm{kg}$. The relatively high $E_{d}$ and $P_{d}$ results obtained in this work were related to the high porosity and large surface 
area of the electrode material for the fabrication of EDLC [102]. The decrement of the EDLC characteristic parameters of energy and power densities at high cycle number was generally caused by the recombination of ions which was due to the increase of internal resistance during the rapid charge-discharge process [103].

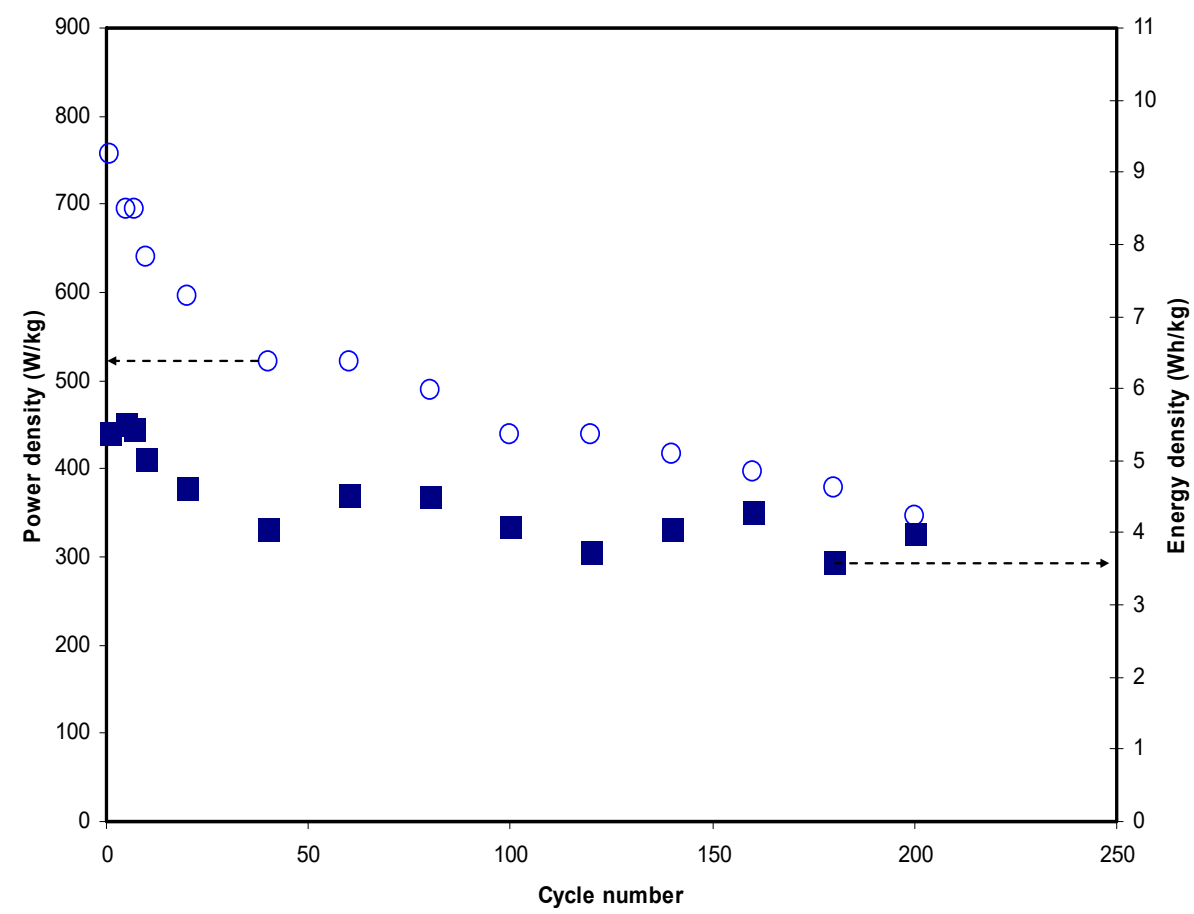

Figure 12. The EDLC energy density $\left(E_{d}\right)$ and power density $\left(P_{d}\right)$ versus cycle number for 200 cycles.

Gomaa A. M. Ali et al. [58] prepared activated carbon using palm kernel shell (ACPKS) and impregnated it with $\mathrm{CaO}$ by eggshell (CaO/ACPKS) as SCs electrodes materials. They showed that the practical symmetrical supercapacitor of $\mathrm{CaO} / \mathrm{ACPKS}$ had high $E_{d}$ of $27.9 \mathrm{~W}$ $\mathrm{h} / \mathrm{kg}$ at a $P_{d}$ of $85.7 \mathrm{~W} \mathrm{~kg}^{-1}$. Gomaa A. M. Ali et al. [104] in another study synthesized grapheme-nanosheets (GNSs) as SCs electrodes. They stated that the GNSs had a specific capacitance of $140 \mathrm{~F} \mathrm{~g}^{-1}$ at $0.05 \mathrm{~A} \mathrm{~g}^{-1}$, and the $E_{d}$ ranged from 5 to $4 \mathrm{Wh} / \mathrm{kg}$ and $P_{d}$ ranged from 135 to $2818 \mathrm{~W} \mathrm{~kg}^{-1}$.Minakshi et al. [105] synthesized a hybrid ESD by sustainable electrode materials. They documented that the hybrid device generated an $E_{d}$ of $35 \mathrm{Wh} / \mathrm{kg}$ and a $P_{d}$ of $420 \mathrm{~W} / \mathrm{kg}$ with long term cyclability of $98 \%$ retention of initial capacitance after 1000 cycles. They showed that the new hybrid ESD, which was prepared from bio-waste materials such as eggshells in combination with cheap and available mixed metal oxides $\left(\mathrm{NiO} / \mathrm{Co}_{3} \mathrm{O}_{4}\right)$, had more applications for numerous energy intensive.

\section{Conclusions}

Summarily, preparation of PVA/MC- $\mathrm{NH}_{4} \mathrm{I}$ PEs was carried out with plasticization using various quantities of glycerol using solution casting methodology. It was concluded that plasticization of PVA/MC- $\mathrm{NH}_{4} \mathrm{I}$ PEs gave a relatively high value of $\mathrm{DC}$ conductivity, which is decisive property to be applicable in EDLC. It was revealed that when the glycerol increased, the mobility, diffusion coefficient and number density of ions gradually increased. It was also confirmed that the relatively high dielectric properties could be achieved when carrier density increased. The transference number measurement (TNM) study presents the electrolyte with $50 \mathrm{wt} . \%$, while glycerol has higher $t_{i o n}$ value than electrolyte with $40 \mathrm{wt} . \%$ glycerol which is 0.917 and 0.882 , respectively. The high $t_{\text {ion }}$ compared to $t_{\text {elec }}$ proves the domination of ion as the conducting species in the electrolyte. From the LSV response, the breakdown voltage of the electrolyte is determined and found to be $1.625 \mathrm{~V}$. From GCD plot, the calculated $C_{S}$ values are found to drop from $47.85 \mathrm{~F} / \mathrm{g}$ to $35.48 \mathrm{~F} / \mathrm{g}$ throughout the 
200 cycles. The increment of internal resistance is shown by ESR plot. The EDLC achieved energy density of $5.38 \mathrm{Wh} / \mathrm{kg}$ at the 1 st cycle and stabilized between 4.54 to $3.59 \mathrm{Wh} / \mathrm{kg}$ from the 60th cycle towards the end. The power density values experienced a step-by-step drop from 757.58 to $347.22 \mathrm{~W} / \mathrm{kg}$.

Author Contributions: Conceptualization, S.B.A. and M.F.Z.K.; Formal analysis, S.B.A. and M.A.B.; Funding acquisition, M.M.N. and E.M.A.D.; Methodology, S.B.A.; Project administration, S.B.A., M.M.N., M.F.Z.K. and E.M.A.D.; Validation, M.M.N., E.M.A.D., M.A.B., J.M.H. and R.M.A.; Writingoriginal draft, S.B.A.; Writing—review \& editing, M.M.N., M.F.Z.K., E.M.A.D., M.A.B., J.M.H. and R.M.A. All authors have read and agreed to the published version of the manuscript.

Funding: This research received no external funding.

Data Availability Statement: Data sharing not applicable.

Acknowledgments: We would like to acknowledge all support for this work by the University of Sulaimani, Prince Sultan University and Komar University of Science and Technology. The authors would like to acknowledge the support of Prince Sultan University for paying the Article Processing Charges (APC) of this publication and for their financial support.

Conflicts of Interest: The authors declare no conflict of interest.

\section{References}

1. Wang, Y.-P.; Gao, X.-H.; Li, H.-K.; Liu, H.-G.; Guo, H.-X.; Li, H.-J. Effect of Active Filler Addition on the Ionic Conductivity of PVDF-PEG Polymer Electrolyte. J. Macromol. Sci. Part A 2009, 46, 461-467. [CrossRef]

2. Brza, M.; Aziz, S.; Anuar, H.; Ali, F. Structural, ion transport parameter and electrochemical properties of plasticized polymer composite electrolyte based on PVA: A novel approach to fabricate high performance EDLC devices. Polym. Test. 2020, $91,106813$. [CrossRef]

3. Pell, W.G.; Conway, B.E. Peculiarities and requirements of asymmetric capacitor devices based on combination of capacitor and battery-type electrodes. J. Power Sources 2004, 136, 334-345. [CrossRef]

4. Wang, H.; Lin, J.; Shen, Z.X. Polyaniline (PANi) based electrode materials for energy storage and conversion. J. Sci. Adv. Mater. Devices 2016, 1, 225-255. [CrossRef]

5. Iro, Z.S.; Subramani, C.; Dash, S.S. A brief review on electrode materials for supercapacitor. Int. J. Electrochem. Sci. 2016, 11, 10628-10643. [CrossRef]

6. Dueramae, I.; Okhawilai, M.; Kasemsiri, P.; Uyama, H.; Kita, R. Properties enhancement of carboxymethyl cellulose with thermo-responsive polymer as solid polymer electrolyte for zinc ion battery. Sci. Rep. 2020, 10, 12587. [CrossRef]

7. Zainol, N.H.; Osman, Z.; Othman, L.; Isa, K.B.M. Transport and Morphological Properties of Gel Polymer Electrolytes Containing $\mathrm{Mg}(\mathrm{CF} 3 \mathrm{SO} 3) 2$. Adv. Mater. Res. 2013, 686, 137-144. [CrossRef]

8. Isa, K.B.M. Magnesium ion-based gel polymer electrolytes: Ionic conduction and infrared spectroscopy studies. Int. J. Electrochem. Sci. 2013, 8, 3602-3614.

9. Buraidah, M.H.; Shah, S.; Teo, L.P.; Chowdhury, F.I.; Careem, M.A.; Albinsson, I.; Mellander, B.-E.; Arof, A.K. High efficient dye sensitized solar cells using phthaloylchitosan based gel polymer electrolytes. Electrochim. Acta 2017, 245, 846-853. [CrossRef]

10. Verma, M.L.; Minakshi, M.; Singh, N.K. Structural and Electrochemical Properties of Nanocomposite Polymer Electrolyte for Electrochemical Devices. Ind. Eng. Chem. Res. 2014, 53, 14993-15001. [CrossRef]

11. Riess, I. Polymeric mixed ionic electronic conductors. Solid State Ionics 2000, 136-137, 1119-1130. [CrossRef]

12. Moniha, V.; Alagar, M.; Selvasekarapandian, S.; Sundaresan, B.; Boopathi, G. Conductive bio-polymer electrolyte iota-carrageenan with ammonium nitrate for application in electrochemical devices. J. Non-Cryst. Solids 2018, 481, 424-434. [CrossRef]

13. Parameswaran, V.; Nallamuthu, N.; Devendran, P.; Nagarajan, E.R.; Manikandan, A. Electrical conductivity studies on Ammonium bromide incorporated with Zwitterionic polymer blend electrolyte for battery application. Phys. B Condens. Matter 2017, 515, 89-98. [CrossRef]

14. Abu Bakar, N.Y.; Muhamaruesa, N.H.M.; Aniskari, N.A.B.; Isa, M.I.N.M. Electrical Studies of Carboxy Methycellulose-Chitosan Blend Biopolymer Doped Dodecyltrimethyl Ammonium Bromide Solid Electrolytes. Am. J. Appl. Sci. 2015, 12, 40-46. [CrossRef]

15. Lim, C.-S.; Teoh, K.H.; Liew, C.-W.; Ramesh, S. Capacitive behavior studies on electrical double layer capacitor using poly (vinyl alcohol)-lithium perchlorate based polymer electrolyte incorporated with $\mathrm{TiO}_{2}$. Mater. Chem. Phys. 2014, 143, 661-667. [CrossRef]

16. Radha, K.P.; Selvasekarapandian, S.; Karthikeyan, S.; Hema, M.; Sanjeeviraja, C. Synthesis and impedance analysis of protonconducting polymer electrolyte PVA:NH4F. Ionics 2013, 19, 1437-1447. [CrossRef]

17. Hema, M.; Selvasekerapandian, S.; Hirankumar, G.; Sakunthala, A.; Arunkumar, D.; Nithya, H. Structural and thermal studies of PVA:NH4I. J. Phys. Chem. Solids 2009, 70, 1098-1103. [CrossRef]

18. Sundaramahalingam, K.; Muthuvinayagam, M.; Nallamuthu, N.; Vanitha, D.; Vahini, M. Investigations on lithium acetate-doped PVA/PVP solid polymer blend electrolytes. Polym. Bull. 2019, 76, 5577-5602. [CrossRef] 
19. Bhuvaneswari, R.; Begam, M.R.; Karthikeyan, S.; Selvasekarapandian, S. Development and characterization of proton conducting polymer electrolyte based on PVA: Arginine: NH4SCN. AIP Conf. 2019, 2115, 030612.

20. Mazuki, N.; Majeed, A.A.; Nagao, Y.; Samsudin, A. Studies on ionics conduction properties of modification CMC-PVA based polymer blend electrolytes via impedance approach. Polym. Test. 2020, 81, 106234. [CrossRef]

21. Liew, C.-W.; Arifin, K.; Kawamura, J.; Iwai, Y.; Ramesh, S.; Arof, A. Electrical and structural studies of ionic liquid-based poly(vinyl alcohol) proton conductors. J. Non-Cryst. Solids 2015, 425, 163-172. [CrossRef]

22. Liew, C.-W.; Ramesh, S.; Arof, A.K. Investigation of ionic liquid-based poly(vinyl alcohol) proton conductor for electrochemical double-layer capacitor. High Perform. Polym. 2014, 26, 632-636. [CrossRef]

23. García, M.; Pinotti, A.; Martino, M.; Zaritzky, N. Electrically treated composite FILMS based on chitosan and methylcellulose blends. Food Hydrocoll. 2009, 23, 722-728. [CrossRef]

24. Shuhaimi, N.E.A.; Alias, N.A.; Kufian, M.Z.; Majid, S.R.; Arof, A.K. Characteristics of methyl cellulose-NH4NO3-PEG electrolyte and application in fuel cells. J. Solid State Electrochem. 2010, 14, 2153-2159. [CrossRef]

25. Samsudin, A.S.; Kuan, E.C.H.; Isa, M.I.N. Investigation of the Potential of Proton-Conducting Biopolymer Electrolytes Based Methyl Cellulose-Glycolic Acid. Int. J. Polym. Anal. Charact. 2011, 16, 477-485. [CrossRef]

26. Misenan, M.; Khiar, A. Conductivity, Dielectric and Modulus Studies of Methylcellulose-NH4TF Polymer. Eurasian J. Biol. Chem. Sci. J. 2018, 1, 59-62.

27. Salleh, N.S.; Aziz, S.B.; Aspanut, Z.; Kadir, M.F.Z. Electrical impedance and conduction mechanism analysis of biopolymer electrolytes based on methyl cellulose doped with ammonium iodide. Ionics 2016, 22, 2157-2167. [CrossRef]

28. Shuhaimi, N.; Teo, L.; Majid, S.; Arof, A. Transport studies of $\mathrm{NH}_{4} \mathrm{NO}_{3}$ doped methyl cellulose electrolyte. Synth. Met. 2010, 160, 1040-1044. [CrossRef]

29. Yusof, Y.M.; Kadir, M.F.Z. Electrochemical characterizations and the effect of glycerol in biopolymer electrolytes based on methylcellulose-potato starch blend. Mol. Cryst. Liq. Cryst. 2016, 627, 220-233. [CrossRef]

30. El-Kader, M.F.H.A.; Ragab, H.S. DC conductivity and dielectric properties of maize starch/methylcellulose blend films. Ionics 2013, 19, 361-369. [CrossRef]

31. Misenan, M.S.B.M.; Isa, M.I.N.M.; Khiar, A.S.A. Electrical and structural studies of polymer electrolyte based on chitosan/methyl cellulose blend doped with BMIMTFSI. Mater. Res. Express 2018, 5, 055304. [CrossRef]

32. Ndruru, S.T.C.L.; Wahyuningrum, D.; Bundjali, B.; Arcana, I.M. Preparation and Characterization of Biopolymer Electrolyte Membranes Based on $\mathrm{LiClO}_{4}$-Complexed Methyl Cellulose as Lithium-ion Battery Separator. J. Eng. Technol. Sci. $2020,52,28$. [CrossRef]

33. Ibrahim, S.; Yasin, S.M.M.; Nee, N.M.; Ahmad, R.; Johan, M.R. Conductivity and dielectric behaviour of PEO-based solid nanocomposite polymer electrolytes. Solid State Commun. 2012, 152, 426-434. [CrossRef]

34. Kumar, M.; Sekhon, S. Role of plasticizer's dielectric constant on conductivity modification of PEO-NH4F polymer electrolytes. Eur. Polym. J. 2002, 38, 1297-1304. [CrossRef]

35. Gong, S.-D.; Huang, Y.; Cao, H.-J.; Lin, Y.-H.; Li, Y.; Tang, S.-H.; Wang, M.-S.; Li, X. A green and environment-friendly gel polymer electrolyte with higher performances based on the natural matrix of lignin. J. Power Sources 2016, 307, 624-633. [CrossRef]

36. Aziz, S.B.; Hamsan, M.H.; Nofal, M.M.; Karim, W.O.; Brevik, I.; Brza, M.; Abdulwahid, R.T.; Al-Zangana, S.; Kadir, M.F. Structural, Impedance and Electrochemical Characteristics of Electrical Double Layer Capacitor Devices Based on Chitosan: Dextran Biopolymer Blend Electrolytes. Polymers 2020, 12, 1411. [CrossRef] [PubMed]

37. Buraidah, M.H.; Arof, A.K. Characterization of chitosan/PVA blended electrolyte doped with $\mathrm{NH}_{4} \mathrm{I}$. J. Non-Cryst. Solids 2011, 357, 3261-3266. [CrossRef]

38. Aziz, S.B.; Hamsan, M.H.; Karim, W.O.; Kadir, M.F.Z.; Brza, M.A.; Abdullah, O.G. High Proton Conducting Polymer Blend Electrolytes Based on Chitosan:Dextran with Constant Specific Capacitance and Energy Density. Biomolecules $2019,9,267$. [CrossRef] [PubMed]

39. Liang, S.; Huang, Q.; Liu, L.; Yam, K.L. Microstructure and Molecular Interaction in Glycerol Plasticized Chitosan/Poly(vinyl alcohol) Blending Films. Macromol. Chem. Phys. 2009, 210, 832-839. [CrossRef]

40. Kuo, C.W.; Huang, C.W.; Chen, B.K.; Li, W.; Bin Chen, P.R.; Ho, T.H.; Tseng, C.G.; Wu, T.Y. Enhanced ionic conductivity in PAM-PEGME-LiClO4-PC composite polymer electrolytes. Int. J. Electrochem. Sci. 2013, 8, 3834-3850.

41. Vignarooban, K.; Dissanayake, M.; Albinsson, I.; Mellander, B.-E. Effect of $\mathrm{TiO}_{2}$ nano-filler and EC plasticizer on electrical and thermal properties of poly(ethylene oxide) (PEO) based solid polymer electrolytes. Solid State Ionics 2014, 266, 25-28. [CrossRef]

42. Shukur, M.F.; Hamsan, M.H.; Kadir, M.F.Z. Investigation of plasticized ionic conductor based on chitosan and ammonium bromide for EDLC application. Mater. Today Proc. 2019, 17, 490-498. [CrossRef]

43. Asnawi, A.S.F.M.; Aziz, S.B.; Nofal, M.M.; Hamsan, M.H.; Brza, M.A.; Yusof, Y.M.; Abdilwahid, R.T.; Muzakir, S.K.; Kadir, M.F.Z. Glycerolized $\mathrm{Li}^{+}$Ion Conducting Chitosan-Based Polymer Electrolyte for Energy Storage EDLC Device Applications with Relatively High Energy Density. Polymers 2020, 12, 1433. [CrossRef] [PubMed]

44. Hamsan, M.H.; Shukur, M.F.; Kadir, M.F.Z. $\mathrm{NH}_{4} \mathrm{NO}_{3}$ as charge carrier contributor in glycerolized potato starch-methyl cellulose blend-based polymer electrolyte and the application in electrochemical double-layer capacitor. Ionics 2017, 23, 3429-3453. [CrossRef]

45. Jayalakshmi, M.; Balasubramanian, K. Simple capacitors to supercapacitors-An overview. Int. J. Electrochem. Sci. 2008, 3, 1196-1217. Available online: http:/ / www.electrochemsci.org/papers/vol3/3111196.pdf (accessed on 20 February 2021). 
46. Zhang, Y.; Feng, H.; Wu, X.; Wang, L.; Zhang, A.; Xia, T.; Dong, H.; Li, X.; Zhang, L. Progress of electrochemical capacitor electrode materials: A review. Int. J. Hydrogen Energy 2009, 34, 4889-4899. [CrossRef]

47. Syahidah, S.N.; Majid, S. Super-capacitive electro-chemical performance of polymer blend gel polymer electrolyte (GPE) in carbon-based electrical double-layer capacitors. Electrochim. Acta 2013, 112, 678-685. [CrossRef]

48. Zhao, X.-Y. Preparation and Characterization of Activated Carbons from Oxygen-rich Lignite for Electric Double-layer Capacitor. Int. J. Electrochem. Sci. 2018, 13, 2800-2816. [CrossRef]

49. Hadi, J.M.; Aziz, S.B.; Saeed, S.R.; Brza, M.A.; Abdulwahid, R.T.; Hamsan, M.H.; Abdullah, R.M.; Kadir, M.F.Z.; Muzakir, S.K. Investigation of Ion Transport Parameters and Electrochemical Performance of Plasticized Biocompatible Chitosan-Based Proton Conducting Polymer Composite Electrolytes. Membranes 2020, 10, 363. [CrossRef]

50. Aziz, S.B.; Hamsan, M.H.; Brza, M.A.; Kadir, M.F.Z.; Abdulwahid, R.T.; Ghareeb, H.O.; Woo, H.J. Fabrication of energy storage EDLC device based on CS:PEO polymer blend electrolytes with high Li+ ion transference number. Results Phys. 2019, 15, 102584. [CrossRef]

51. Stavrinidou, E.; Sessolo, M.; Winther-Jensen, B.; Sanaur, S.; Malliaras, G.G. A physical interpretation of impedance at conducting polymer/electrolyte junctions. AIP Adv. 2014, 4, 017127. [CrossRef]

52. Aziz, S.B.; Marf, A.S.S.; Dannoun, E.M.A.; Brza, M.A.; Abdullah, R.M. The Study of the Degree of Crystallinity, Electrical Equivalent Circuit, and Dielectric Properties of Polyvinyl Alcohol (PVA)-Based Biopolymer Electrolytes. Polymers 2020, $12,2184$. [CrossRef]

53. Hadi, J.M.; Aziz, S.B.; Mustafa, M.S.; Hamsan, M.H.; Abdulwahid, R.T.; Kadir, M.F.Z.; Ghareeb, H.O. Role of nano-capacitor on dielectric constant enhancement in PEO:NH4SCN:xCeO2 polymer nano-composites: Electrical and electrochemical properties. J. Mater. Res. Technol. 2020, 9, 9283-9294. [CrossRef]

54. Thalji, M.R.; Ali, G.A.; Algarni, H.; Chong, K.F. Al ${ }^{3+}$ ion intercalation pseudocapacitance study of W18O49 nanostructure. J. Power Sources 2019, 438, 227028. [CrossRef]

55. Ali, G.A.; Megiel, E.; Romański, J.; Algarni, H.; Chong, K.F. A wide potential window symmetric supercapacitor by TEMPO functionalized MWCNTs. J. Mol. Liq. 2018, 271, 31-39. [CrossRef]

56. Ali, G.; Manaf, S.A.B.A.; Kumar, A.; Chong, K.F.; Hegde, G. High performance supercapacitor using catalysis free porous carbon nanoparticles. J. Phys. D Appl. Phys. 2014, 47, 495307. [CrossRef]

57. Ali, G.A.M.; Thalji, M.R.; Soh, W.C.; Algarni, H.; Chong, K.F. One-step electrochemical synthesis of MoS2/graphene composite for supercapacitor application. J. Solid State Electrochem. 2019, 24, 25-34. [CrossRef]

58. Ali, G.A.M.; Habeeb, O.A.; Algarni, H.; Chong, K.F. CaO impregnated highly porous honeycomb activated carbon from agriculture waste: Symmetrical supercapacitor study. J. Mater. Sci. 2018, 54, 683-692. [CrossRef]

59. Pradhan, D.K.; Choudhary, R.N.P.; Samantaray, B.K. Studies of structural, thermal and electrical behavior of polymer nanocomposite electrolytes. Express Polym. Lett. 2008, 2, 630-638. [CrossRef]

60. Aziz, S.B.; Hadi, J.M.; Dannoun, E.M.A.; Abdulwahid, R.T.; Saeed, S.R.; Marf, A.S.; Karim, W.O.; Kadir, M.F. The Study of Plasticized Amorphous Biopolymer Blend Electrolytes Based on Polyvinyl Alcohol (PVA): Chitosan with High Ion Conductivity for Energy Storage Electrical Double-Layer Capacitors (EDLC) Device Application. Polymers 2020, 12, 1938. [CrossRef]

61. Hamsan, M.H.; Aziz, S.B.; Nofal, M.M.; Brza, M.A.; Abdulwahid, R.T.; Hadi, J.M.; Karim, W.O.; Kadir, M.F.Z. Characteristics of EDLC device fabricated from plasticized chitosan:MgCl2 based polymer electrolyte. J. Mater. Res. Technol. 2020, 9, 10635-10646. [CrossRef]

62. Hadi, J.M.; Aziz, S.B.; Mustafa, M.S.; Brza, M.A.; Hamsan, M.H.; Kadir, M.F.Z.; Ghareeb, H.O.; Hussein, S.A. Electrochemical Impedance study of Proton Conducting Polymer Electrolytes based on PVC Doped with Thiocyanate and Plasticized with Glycerol. Int. J. Electrochem. Sci. 2020, 15, 4671-4683. [CrossRef]

63. Alipoori, S.; Mazinani, S.; Aboutalebi, S.H.; Sharif, F. Review of PVA-based gel polymer electrolytes in flexible solid-state supercapacitors: Opportunities and challenges. J. Energy Storage 2020, 27, 101072. [CrossRef]

64. Zhao, C.; Wang, C.; Yue, Z.; Shu, K.; Wallace, G.G. Intrinsically Stretchable Supercapacitors Composed of Polypyrrole Electrodes and Highly Stretchable Gel Electrolyte. ACS Appl. Mater. Interfaces 2013, 5, 9008-9014. [CrossRef]

65. Aziz, S.B.; Hamsan, M.H.; Karim, W.O.; Marif, A.S.; Abdulwahid, R.T.; Kadir, M.F.Z.; Brza, M.A. Study of impedance and solid-state double-layer capacitor behavior of proton $(\mathrm{H}+)$-conducting polymer blend electrolyte-based CS:PS polymers. Ionics 2020, 26, 4635-4649. [CrossRef]

66. Aziz, S.B.; Hamsan, M.H.; Abdullah, R.M.; Abdulwahid, R.T.; Brza, M.A.; Marif, A.S.; Kadir, M.F.Z. Protonic EDLC cell based on chitosan (CS): Methylcellulose (MC) solid polymer blend electrolytes. Ionics 2020, 26, 1829-1840. [CrossRef]

67. Brza, M.; Aziz, S.B.; Saeed, S.R.; Hamsan, M.H.; Majid, S.R.; Abdulwahid, R.T.; Kadir, M.F.Z.; Abdullah, R.M. Energy Storage Behavior of Lithium-Ion Conducting poly(vinyl alcohol) (PVA): Chitosan(CS)-Based Polymer Blend Electrolyte Membranes: Preparation, Equivalent Circuit Modeling, Ion Transport Parameters, and Dielectric Properties. Membranes 2020, $10,381$. [CrossRef] [PubMed]

68. Pradhan, D.K.; PChoudhary Samantaray, B.K.; Karan, N.K.; Katiyar, R.S. Effect of Plasticizer on Structural and Electrical Properties of Polymer Nanocompsoite Electrolytes. Int. J. Electrochem. Sci. 2007, 2, 861-871.

69. Brza, M.A.; Aziz, S.B.; Anuar, H.; Dannoun, E.M.A.; Ali, F.; Abdulwahid, R.T.; Al-Zangana, S.; Kadir, M.F. The Study of EDLC Device with High Electrochemical Performance Fabricated from Proton Ion Conducting PVA-Based Polymer Composite Electrolytes Plasticized with Glycerol. Polymers 2020, 12, 1896. [CrossRef] 
70. Hadi, J.M.; Aziz, S.B.; Nofal, M.M.; Hussein, S.A.; Hamsan, M.H.; Brza, M.A.; Abdulwahid, R.T.; Kadir, M.F.Z.; Woo, H.J. Electrical, Dielectric Property and Electrochemical Performances of Plasticized Silver Ion-Conducting Chitosan-Based Polymer Nanocomposites. Membranes 2020, 10, 151. [CrossRef]

71. Aziz, S.B.; Abdullah, R.M. Crystalline and amorphous phase identification from the tan $\delta$ relaxation peaks and impedance plots in polymer blend electrolytes based on [CS:AgNt]x:PEO(x-1) $(10 \leq x \leq 50)$. Electrochim. Acta 2018, 285, 30-46. [CrossRef]

72. Zulkifli, A.M. Electrochemical Characteristics of Phthaloyl Chitosan Based Gel Polymer Electrolyte for Dye Sensitized Solar Cell Application. Int. J. Electrochem. Sci. 2020, 15, 7434-7447. [CrossRef]

73. TianKhoon, L.; Ataollahi, N.; Hassan, N.H.; Ahmad, A. Studies of porous solid polymeric electrolytes based on poly (vinylidene fluoride) and poly (methyl methacrylate) grafted natural rubber for applications in electrochemical devices. J. Solid State Electrochem. 2015, 20, 203-213. [CrossRef]

74. Aziz, S.B.; Abidin, Z.H.Z. Ion-transport study in nanocomposite solid polymer electrolytes based on chitosan: Electrical and dielectric analysis. J. Appl. Polym. Sci. 2015, 132, 41774. [CrossRef]

75. Zulkifli, A.M.; Said, N.I.A.M.; Aziz, S.B.; Dannoun, E.M.A.; Hisham, S.; Shah, S.; Abu Bakar, A.; Zainal, Z.H.; Tajuddin, H.A.; Hadi, J.M.; et al. Characteristics of Dye-Sensitized Solar Cell Assembled from Modified Chitosan-Based Gel Polymer Electrolytes Incorporated with Potassium Iodide. Molecules 2020, 25, 4115. [CrossRef] [PubMed]

76. Aziz, S.B.; Abidin, Z.H.Z. Electrical and morphological analysis of chitosan:AgTf solid electrolyte. Mater. Chem. Phys. 2014, 144, 280-286. [CrossRef]

77. Aziz, S.B.; Brza, M.A.; Hamsan, E.M.A.D.M.H.; Hadi, J.M.; Kadir, M.F.Z.; Abdulwahid, R.T. The Study of Electrical and Electrochemical Properties of Magnesium Ion Conducting CS: PVA Based Polymer Blend Electrolytes: Role of Lattice Energy of Magnesium Salts on EDLC Performance. Molecules 2020, 25, 4503. [CrossRef] [PubMed]

78. Basha, S.S.; Rao, M.C. Spectroscopic and Electrochemical Properties of (1-x)[PVA/PVP]: X[MgCl $\left.{ }_{2}\left\{6 \mathrm{H}_{2} \mathrm{O}\right\}\right]$ Blend Polymer Electrolyte Films. Int. J. Polym. Sci. 2019, 2019, 8095237. [CrossRef]

79. Aziz, S.B.; Hamsan, M.H.; Brza, M.A.; Kadir, M.F.Z.; Muzakir, S.K.; Abdulwahid, R.T. Effect of glycerol on EDLC characteristics of chitosan:methylcellulose polymer blend electrolytes. J. Mater. Res. Technol. 2020, 9, 8355-8366. [CrossRef]

80. Nofal, M.M.; Aziz, S.B.; Hadi, J.M.; Abdulwahid, R.T.; Dannoun, E.M.A.; Marif, A.S.; Al-Zangana, S.; Zafar, Q.; Brza, M.A.; Kadir, M.F.Z. Synthesis of Porous Proton Ion Conducting Solid Polymer Blend Electrolytes Based on PVA: CS Polymers: Structural, Morphological and Electrochemical Properties. Materials 2020, 13, 4890. [CrossRef]

81. Sampathkumar, L.; Selvin, P.C.; Selvasekarapandian, S.; Perumal, P.; Chitra, R.; Muthukrishnan, M. Synthesis and characterization of biopolymer electrolyte based on tamarind seed polysaccharide, lithium perchlorate and ethylene carbonate for electrochemical applications. Ionics 2019, 25, 1067-1082. [CrossRef]

82. Noor, N.A.M.; Isa, M.I.N. Investigation on transport and thermal studies of solid polymer electrolyte based on carboxymethyl cellulose doped ammonium thiocyanate for potential application in electrochemical devices. Int. J. Hydrogen Energy 2019, 44, 8298-8306. [CrossRef]

83. Asnawi, A.S.F.M.; Aziz, S.B.; Nofal, M.M.; Yusof, Y.M.; Brevik, I.; Hamsan, M.H.; Brza, M.A.; Abdulwahid, R.T.; Kadir, M.F.Z. Metal Complex as a Novel Approach to Enhance the Amorphous Phase and Improve the EDLC Performance of Plasticized Proton Conducting Chitosan-Based Polymer Electrolyte. Membranes 2020, 10, 132. [CrossRef]

84. Pratap, R.; Singh, B.; Chandra, S. Polymeric rechargeable solid-state proton battery. J. Power Sources 2006, 161, 702-706. [CrossRef]

85. Böckenfeld, N.; Willeke, M.; Pires, J.; Anouti, M.; Balducci, A. On the Use of Lithium Iron Phosphate in Combination with Protic Ionic Liquid-Based Electrolytes. J. Electrochem. Soc. 2013, 160, A559-A563. [CrossRef]

86. Ali, G.A.M.; Divyashree, A.; Supriya, S.; Chong, K.F.; Ethiraj, A.S.; Reddy, M.V.; Algarni, H.; Hegde, G. Carbon nanospheres derived from Lablab purpureus for high performance supercapacitor electrodes: A green approach. Dalton Trans. 2017, 46, 14034-14044. [CrossRef] [PubMed]

87. Farah, N.; Ng, H.; Numan, A.; Liew, C.-W.; Latip, N.; Ramesh, K.; Ramesh, S. Solid polymer electrolytes based on poly(vinyl alcohol) incorporated with sodium salt and ionic liquid for electrical double layer capacitor. Mater. Sci. Eng. B 2019, $251,114468$. [CrossRef]

88. Kumar, A.; Logapperumal, S.; Sharma, R.; Das, M.K.; Kar, K.K. Li-ion transport, structural and thermal studies on lithium triflate and barium titanate incorporated poly(vinylidene fluoride-co-hexafluoropropene) based polymer electrolyte. Solid State Ionics 2016, 289, 150-158. [CrossRef]

89. Kang, J.; Wen, J.; Jayaram, S.H.; Yu, A.; Wang, X. Development of an equivalent circuit model for electrochemical double layer capacitors (EDLCs) with distinct electrolytes. Electrochim. Acta 2014, 115, 587-598. [CrossRef]

90. Aziz, S.B.; Hamsan, M.H.; Kadir, M.F.Z.; Karim, W.O.; Abdullah, R.M. Development of Polymer Blend Electrolyte Membranes Based on Chitosan: Dextran with High Ion Transport Properties for EDLC Application. Int. J. Mol. Sci. 2019, 20, 3369. [CrossRef]

91. Wang, J.; Zhao, Z.; Song, S.; Ma, Q.; Liu, R. High Performance Poly(vinyl alcohol)-Based Li-Ion Conducting Gel Polymer Electrolyte Films for Electric Double-Layer Capacitors. Polymers 2018, 10, 1179. [CrossRef]

92. Navale, Y.; Navale, S.; Dhole, I.; Stadler, F.; Patil, V. Specific capacitance, energy and power density coherence in electrochemically synthesized polyaniline-nickel oxide hybrid electrode. Org. Electron. 2018, 57, 110-117. [CrossRef]

93. Ali, G.A.; Yusoff, M.M.; Shaaban, E.R.; Chong, K.F. High performance $\mathrm{MnO}_{2}$ nanoflower supercapacitor electrode by electrochemical recycling of spent batteries. Ceram. Int. 2017, 43, 8440-8448. [CrossRef] 
94. Aziz, S.; Dannoun, E.; Hamsan, M.; Ghareeb, H.; Nofal, M.; Karim, W.; Asnawi, A.; Hadi, J.; Kadir, M. A Polymer Blend Electrolyte Based on CS with Enhanced Ion Transport and Electrochemical Properties for Electrical Double Layer Capacitor Applications. Polymers 2021, 13, 930. [CrossRef] [PubMed]

95. Yusof, Y.M.; Majid, N.A.; Kasmani, R.M.; Illias, H.A.; Kadir, M.F.Z. The Effect of Plasticization on Conductivity and Other Properties of Starch/Chitosan Blend Biopolymer Electrolyte Incorporated with Ammonium Iodide. Mol. Cryst. Liq. Cryst. 2014, 603, 73-88. [CrossRef]

96. Acharya, S.; Hu, Y.; Moussa, H.; Abidi, N. Preparation and characterization of transparent cellulose films using an improved cellulose dissolution process. J. Appl. Polym. Sci. 2017, 134, 1-12. [CrossRef]

97. Azli, A.A.; Manan, N.S.A.; Aziz, S.B.; Kadir, M.F.Z. Structural, impedance and electrochemical double-layer capacitor characteristics of improved number density of charge carrier electrolytes employing potato starch blend polymers. Ionics 2020, 26, 5773-5804. [CrossRef]

98. Ali, G.A.; Manaf, S.A.A.; Divyashree, A.; Chong, K.F.; Hegde, G. Superior supercapacitive performance in porous nanocarbons. J. Energy Chem. 2016, 25, 734-739. [CrossRef]

99. Sundaram, M.M.; Appadoo, D. Traditional salt-in-water electrolyte vs. water-in-salt electrolyte with binary metal oxide for symmetric supercapacitors: Capacitive vs. faradaic. Dalton Trans. 2020, 49. [CrossRef]

100. Biswal, A.; Panda, P.K.; Acharya, A.N.; Tripathy, B.C.; Alenazey, F.S.; Jiang, Z.-T.; Sundaram, M.M. Tuning the morphology and redox behaviour by varying the concentration of $\mathrm{Fe}$ in a CoNiFe ternary oxide heterostructure for hybrid devices. New J. Chem. 2020, 44, 9921-9932. [CrossRef]

101. Shukur, M.F.; Ithnin, R.; Kadir, M.F.Z. Electrical characterization of corn starch-LiOAc electrolytes and application in electrochemical double layer capacitor. Electrochim. Acta 2014, 136, 204-216. [CrossRef]

102. Biswal, A.; Panda, P.K.; Acharya, A.N.; Mohapatra, S.; Swain, N.; Tripathy, B.C.; Jiang, Z.-T.; Sundaram, M.M. Role of Additives in Electrochemical Deposition of Ternary Metal Oxide Microspheres for Supercapacitor Applications. ACS Omega 2020, 5, 3405-3417. [CrossRef]

103. Zhong, C.; Deng, Y.; Hu, W.; Qiao, J.; Zhang, L.; Zhang, J. A review of electrolyte materials and compositions for electrochemical supercapacitors. Chem. Soc. Rev. 2015, 44, 7484-7539. [CrossRef] [PubMed]

104. Ali, G.A.; Makhlouf, S.A.; Yusoff, M.M.; Chong, K.F. Structural and electrochemical characteristics of graphene nanosheets as supercapacitor electrodes. Rev. Adv. Mater. Sci. 2015, 40, 35-43.

105. Minakshi, M.; Mitchell, D.R.G.; Jones, R.T.; Pramanik, N.C.; Jean-Fulcrand, A.; Garnweitner, G. A Hybrid Electrochemical Energy Storage Device Using Sustainable Electrode Materials. ChemestrySelect 2020, 5, 1597-1606. [CrossRef] 